Review

\title{
Aqueous and Ethanolic Plant Extracts as Bio-Insecticides-Establishing a Bridge between Raw Scientific Data and Practical Reality
}

\author{
Wilson R. Tavares ${ }^{1}\left[\right.$, Maria do Carmo Barreto ${ }^{1, *}$ and Ana M. L. Seca $1,2, * \mathbb{C}$ \\ 1 cE3c-Centre for Ecology, Evolution and Environmental Changes / Azorean Biodiversity Group \& Faculty of \\ Sciences and Technology, University of Azores, Rua Mãe de Deus, 9501-321 Ponta Delgada, Portugal; \\ wilson.r.tavares@uac.pt \\ 2 LAQV-REQUIMTE, Department of Chemistry, University of Aveiro, 3810-193 Aveiro, Portugal \\ * Correspondence: maria.cr.barreto@uac.pt (M.d.C.B.); ana.ml.seca@uac.pt (A.M.L.S.); \\ Tel.: +351-296-650-184 (M.d.C.B.); +351-296-650-172 (A.M.L.S.)
}

Citation: Tavares, W.R.; Barreto,

M.d.C.; Seca, A.M.L. Aqueous and Ethanolic Plant Extracts as

Bio-Insecticides-Establishing a Bridge between Raw Scientific Data and Practical Reality. Plants 2021, 10, 920. https://doi.org/10.3390/ plants10050920

Academic Editor: Paula Baptista

Received: 9 April 2021

Accepted: 30 April 2021

Published: 4 May 2021

Publisher's Note: MDPI stays neutral with regard to jurisdictional claims in published maps and institutional affiliations.

Copyright: (C) 2021 by the authors. Licensee MDPI, Basel, Switzerland. This article is an open access article distributed under the terms and conditions of the Creative Commons Attribution (CC BY) license (https:// creativecommons.org/licenses/by/ $4.0 /)$.

\begin{abstract}
Global demand for food production is causing pressure to produce faster and bigger crop yields, leading to a rampant use of synthetical pesticides. To combat the nefarious consequences of its uses, a search for effective alternatives began in the last decades and is currently ongoing. Nature is seen as the main source of answers to crop protection problems, supported by several examples of plants/extracts used for this purpose in traditional agriculture. The literature reviewed allowed the identification of 95 plants whose extracts exhibit insecticide activity and can be used as bio-pesticides contributing to sustainable agriculture. The option for ethanol and/or water extracts is more environmentally friendly and resorts to easily accessible solvents, which can be reproduced by farmers themselves. This enables a bridge to be established between raw scientific data and a more practical reality. Azadirachta indica, Capsicum annuum, Nicotiana tabacum and Tagetes erecta are the most researched plants and have the potential to be viable options in the pest management approach. Azadirachta indica showed the most promising results and Brevicoryne brassicae was the most targeted pest species, being tested against the aqueous and/or ethanolic extracts of 23 different plants. Maceration using dried material (usually leaves) is the extraction method preferred by the majority of authors.
\end{abstract}

Keywords: bio-insecticides; aqueous extracts; ethanolic extracts; plant extracts; crop pest management; Azadirachta indica; Capsicum annuum; Nicotiana tabacum; Tagetes erecta

\section{Introduction}

Agriculture was fundamental in the development of human society, enabling a gradual shift from a hunter-gatherer nomadic lifestyle to a more settled way of life, allowing primordial civilizations to flourish [1]. Since then, its role in the success of humans has only grown, and currently its importance is at its peak due to the globally rising demand for food production [2]. In recent years, there has been an unsustainable intensification of agriculture, causing an increase in the use of chemicals to allow bigger, faster and pest-free crop productions [3].

The emergence of insect pests in crops represents a serious problem, since they decrease the yield of production leading to considerable losses of time and money invested [4]. Synthetic insecticides are commonly chosen to tackle that problem, since they offer a solution that is often quick and effective, acting almost instantly and not requiring much labour-intensive work to be applied [5,6]. Unfortunately, the continued use of these chemicals can lead to various environmental problems $[7,8]$, with harmful consequences for various living beings [9-11] and also affecting human health [12-15]. Additionally, the intensive use of synthetic pesticides in the last century has caused an increase in resistance 
by crop pests [16], with reports of insecticide resistance going as far back as 1897, when John B. Smith reported the observation of resistance to kerosene of the San Jose scale (Quadraspidiotus perniciosus) [17].

To avoid the negative points inherent to the use of synthetic insecticides, it is necessary to find more efficient alternatives with less environmental impact that can control the pest populations [18]. Furlan and colleagues [19] reviewed the various alternatives to systemic insecticides in agriculture. From landscape manipulation to changes in the established farming practices, or using specific organisms to combat the pests or traps to catch them, the pest management tactics are diverse [19]. One of those tactics is the use of naturally derived insecticides, such as plant extracts, that are more environmentally friendly and sustainable than the commercial synthetic insecticides widely used in agriculture [20]. According to their production method, botanical insecticides can be grouped in two major categories: i.e., commercial botanical insecticides and farm products. The first group is composed of products developed by companies with a commercial aim, basing their formulations on active substances obtained from selected plant species with reported insecticide properties. The second group consists of products produced by rural farmers according to traditional recipes and/or popular knowledge of pesticidal effects of some plants in the area of their local use passed on for generations [21].

As an evolutionary response to the environment, plants can modulate their behaviour in order to succeed in nature [22], developing specialized morphological structures and synthesizing several products to try to ensure their survival against insects and other predators $[23,24]$. Secondary metabolites are produced, with specific properties against different insects, such as antinutritional, repellent, and/or toxic effects [25]. Humans have always observed these effects and started to experiment with different plants to take advantage of these insecticide properties to protect crops. For example, the ancient Greeks and Romans believed that if seeds were sowed just before a new moon and after being mixed with crushed cypress (Cupressus spp.) leaves, they would be protected from maggots [26]. One of India's oldest documents describes the use of several plants to protect crops, such as a powdered mixture of the roots of five plants (i.e., Aegle marmelos (L.) Corrêa, Clerodendrum phlomidis L.f., Gmelina arborea Roxb., Stereospermum chelonoides (L.f.) DC. (syn. Stereospermum suaveolens (Roxb.) DC.) and Oroxylum indicum (L.) Kurz) which was used to restore plant health [27].

The use of plants to protect crops against insect pests is not just a practice of ancient civilizations. This practice continues to be used by farmers around the world, mainly in areas where access to synthetic pesticides is more difficult and in organic farming, using plants in the form of extracts, company plants or just the harvested plant [28-31]. Some examples of this reality are presented below.

In Ghana, chilli peppers (Capsicum annuum L.) and orange (Citrus sinensis (L.) Osbeck) peel are well-known for their protection effect of stored crops against insect pests, as well as Azadirachta indica A.Juss., Cymbopogon schoenanthus (L.) Spreng., Securidaca longipedunculata Fresen. and Senna sophera (L.) Roxb. (syn. Cassia sophera L.) [28]. Most of the plants are used individually or in a mixture with other pesticidal plants, after being pounded and turned into a powder to mix with the crop before storage, although other methods of application are described [28]. Local farmers in Kenya use aqueous concoctions of Azadirachta indica and Capsicum annuum for insect pest control [32]. In addition to the aqueous extracts, ashes from cow dung mixed with the pesticidal plants are also used to protect stored crops [32]. According to the rural farmers in Malawi and Zambia, the cultural practices against insect pests using plants mainly involve the use of locally available plants known for their insecticide and repellent properties, such as Azadirachta indica, Bobgunnia madagascariensis (Desv.) J.H.Kirkbr. \& Wiersema, Euphorbia tirucalli L., Nicotiana tabacum L., Tithonia diversifolia (Hemsl.) A.Gray, Toona ciliata M.Roem. and Tephrosia vogelii Hook.f., being Tephrosia vogelii the most widely used plant in both regions $[33,34]$. These plants are particularly effective against bollworms and red spider mites affecting tomato crops and against aphids, diamond back moths and webworms affecting cruciferous vegetables 
crops [34]. In addition, powdered Bobgunnia madagascariensis is popular in Malawi for its molluscicide properties [35].

In Sri Lanka, Croton laccifer L. branches are detached from the plant and beaten to damage their leaves, originating a strong odour that repels rice bugs present in rice crops. Another technique used to repel these bugs is to burn chipped wood of Cerbera manghas L. near the rice fields [36]. Some communities in India store their crops in cylindrical basket-like structures made with Borassus flabellifer L. leaves tightly woven to prevent the entry of insects. In addition, leaves of local plants known to have insect deterrent action are used as inner lining of the basket, i.e., Azadirachta indica, Psidium guajava L., Vitex negundo L. and Pongamia pinnata (L.) Pierre [37]. Indian communities in the south of the country report other pest control techniques, such as the placement of leaves of Azadirachta indica, Coriandrum sativum L., Leucas aspera (Willd.) Link or Pongamia pinnata as layers between the crop sacks stacked one above the other in storehouses [38]. According to the locals, the strong odour of the leaves is effective in keeping away pests such as Cryptolestes minutus, Ephestia cautella, Latheticus oryzae, Oryzaephilus surinamensis, Rhyzopertha dominica and Tribolium castaneum. Acorus calamus L., Azadirachta indica and lime (Citrus spp.) powders can also be used for the same purpose [38]. Another example is the application of Areca catech $u \mathrm{~L}$. fruits and leaves suspended from wooden beams in small storages of rice to repel insect pests in rural farming communities of the Philippines [39]. To control the damage of cotton plantations (Gossypium spp.) by the bollworm (Helicoverpa armigera), farmers in Benin use mixtures of Hyptis suaveolens (L.) Poit., Khaya senegalensis (Desv.) A.Juss. and Azadirachta indica to spray on the cotton plants [40].

In Cameroon, Cannabis sativa L. is widely used by farmers of cacao plantations (Theobroma cacao L.) to control cacao pests, particularly capsids insect populations, being planted side-by-side with the cacao plant to act as a deterrent for the pests [41]. Furthermore, the Cannabis sativa aqueous extract is obtained from fresh or dried pounded leaves and is applied alone or in mixture with other local insecticidal plants extracts (i.e., Ceiba pentandra (L.) Gaertn., Erythrophleum ivorense A.Chev., Guibourtia tessmannii (Harms) J.Leonard, Nicotiana tabacum and Pachyelasma tessmannii (Harms) Harms). According to the farmers, the number of species used influences the effectiveness of the extracts, the more diversified the extract mixture, the better [41]. Similarly, in Uganda, the use of mixtures of various plant parts (bark, flowers, leaves, roots, seeds and stems) from different plant species (Azadirachta indica, Cannabis sativa, Capsicum annuum L. (syn. Capsicum frutescens L.), Cupressus lusitanica Mill., Moringa oleifera Lam., Musa spp., Nicotiana tabacum, Tagetes erecta L., Tagetes minuta L. and Tephrosia vogelii) is common for field and stored crop protections [42]. In this case, the plants alone or mixtures of them are burnt to obtain plant ash that is then applied on the crops to control insect pests such as stem borer (Busseola fusca), banana weevil (Cosmopolites sordidus), bean fly (Ophiomyia phaseoli) grain moth (Sitotroga cerealella), pod borers (Maruca vitrata and Nezara viridula) and aphids (Aphis craccivora, Aphis fabae and Rhopalosiphum maidis) [42].

The traditional uses of plants as insecticides addressed above show that several species are used in different ways, depending on the location of the report, with some plants deeply rooted in popular knowledge being mentioned regularly, e.g., Azadirachta indica and Nicotiana tabacum. These reports do not usually allow for exact conclusions to be drawn regarding the effectiveness of the plants mentioned, since only the testimony of rural farmers is considered, lacking, in many cases, scientific evidence to support their claims. However, these information demonstrate the value of popular knowledge in providing scientists with good starting points in their search for promising sources of new bioactive natural compounds with insecticide properties [43,44].

In addition, pure compounds with insecticidal action have been isolated from several plants, such as Azadirachtin (isolated from Azadirachta indica) and pyrethrins (isolated from Tanacetum cinerariifolium (Trevir.) Sch.Bip.), which are two cases of successful natural insecticides, being the base of the majority of current commercial botanical insecticides [45-47]. 
However, this kind of insecticides tends to be difficult to obtain by most smallholder farmers since they are relatively expensive, making crops economically unsustainable [48].

This review was elaborated to provide reliable scientific information regarding plants with insecticide properties to anyone who wants to try a more natural approach to pest management. To promote sustainable practices, this work contemplates only studies performed with easily accessible and environmentally friendly solvents, such as ethanol and water, leaving out the literature on insecticide activities exhibited by other organic extracts, essential oils and pure compounds. The research for this review was made crossing the terms bio-insecticide, ethanol plant extracts, water plant extracts, insecticide activity and crop pests in the databases Web of Science, PubMed and Scopus, and only the published works involving plant species with an accepted binominal Latin name on the "The Plant List" database were considered [49].

\section{Plant Extracts as Bio-Insecticides}

To be a viable alternative to synthetic insecticides, bio-insecticides must be affordable (based on plant materials readily available and cheap) and be simple to prepare (not requiring complex equipment and solvents which are either toxic or difficult to buy) [50]. Furthermore, the resultant bio-insecticide should have low phytotoxicity, causing no negative effects on crop yields, being also benign to the natural enemies of the targeted pest, and avoiding resurgent and new pests [51,52]. Thus, in this next section, aqueous and ethanolic plant extracts with reported insecticidal properties against common crop pests, and which could be considered as potential effective bio-insecticides, will be discussed.

In recent years, various works have been carried out to ascertain whether some plant extracts have the insecticide potential to become a reliable choice over synthetic insecticides, with some of them showing very interesting results [47,53]. The bibliographic research carried out revealed some works whose experimental design, activity level and/or conclusions deserve a more detailed discussion, being presented below.

\subsection{Aqueous Extracts}

To provide farmers with quick and cheap access to crop pest control solutions, Mkenda et al. [54] analysed the insecticide potential of four abundant plant species found in Tanzania. Aqueous leaf extracts of Tephrosia vogelii, Tithonia diversifolia, Vernonia amygdalina Delile and Lippia javanica (Burm.f.) Spreng. provided effective control against common pests of the bean plant Phaseolus vulgaris L., i.e., aphids (Aphis fabae), flower beetles (Epicauta albovittata and Epicauta limbatipennis) and bean foliage beetles (Ootheca mutabilis and Ootheca bennigseni). Vernonia amygdalina extract provided control of flower beetles comparable to the synthetic insecticide Karate ${ }^{\circledR}$. In fact, average insect abundance using Vernonia amygdalina extract $(1$ and $10 \% w / v)$ was 0.63 , using Karate ${ }^{\circledR}(2.5 \mathrm{mg} / \mathrm{mL})$ it was 0.37 , while in the untreated plants it was 2.45. Lippia javanica and Vernonia amygdalina were generally more effective in reducing pest insect incidence, abundance and damage than Tephrosia vogelii and Tithonia diversifolia. However, treatments with Tephrosia vogelii and Tithonia diversifolia produced significantly higher crop yields than all other treatments, which the authors attributed to the lowest impact of these two treatments on the numbers of auxiliary agents, such as lady beetles and spiders [54]. The impact of a bio-pesticide on auxiliary control agents is a valuable and interesting variable that should be taken into account in works that evaluate the insecticide potential of plant extracts, but which unfortunately is often overlooked by researchers.

In a study involving the aphid Brevicoryne brassicae [55], nine aqueous extracts were tested for their repellent and insecticide properties. Two different extraction techniques (cold extraction of dry material and infusion of fresh material) and different parts of the plants (flowers, fruits and leaves) were used to obtain the plant extracts that were further sprayed at different concentrations $(1,2.5,5$ and $10 \% \mathrm{w} / \mathrm{v})$ over the studied insects. The most effective extracts as repellents were the ones from the fresh fruits of Solanum guaraniticum A. St.-Hil. (syn. Solanum fastigiatum var. acicularium Dunal) and Solanum 
pseudocapsicum L. (syn. Solanum diflorum Vell.) (both at 2.5 and 5\% concentrations). Leaf extracts of Solanum guaraniticum and Solanum bonariense L. (syn. Solanum fastigiatum var. fastigiatum) (10\% concentration) demonstrated to be the most effective treatments regarding the insecticide capacity, affecting the reproduction and survival of Brevicoryne brassicae.

Rando et al. [56] assessed the insecticide properties of water extracts (at 10\% $w / v$ ) of Coriandrum sativum, Equisetum hyemale L., Nicotiana tabacum and Ocimum gratissimum L., sprayed against Brevicoryne brassicae and Myzus persicae. The results showed that only Coriandrum sativum and Nicotiana tabacum extract were effective after $72 \mathrm{~h}$ of treatment against both pests, presenting mortality rates similar to the organophosphate insecticide acephate used as control. Equisetum hyemale and Ocimum gratissimum also presented insecticide properties but only against Brevicoryne brassicae.

Nicotiana megalosiphon Van Heurck \& Müll.Arg. was studied to assess the insecticidal properties of its aqueous extract against the common pests of cabbage (Brassica oleracea L.), such as the cabbage aphid (Brevicoryne brassicae), the green peach aphid (Myzus persicae) and the diamondback moth (Plutella xylostella) [57]. The extracts at 1\%,5\% and 10\% w/v (grams of plant per $100 \mathrm{~mL}$ of tap water) were able to control the population numbers of all pest species, presenting the highest effect against Plutella xylostella (mortality of $25 \pm 0.03 \%, 90 \pm 0.04 \%$ and $100 \pm 0.00 \%$, respectively), $24 \mathrm{~h}$ after treatment, being better than the reference insecticide tau-fluvalinate at $7.5 \mathrm{~g} / \mathrm{L}$ diluted as recommended by the manufacturer to $9.5 \mathrm{~mL} / \mathrm{L}$, that just presented a mortality rate of $22 \pm 0.05 \%$.

Aphis gossypii was the target in the work of Santos et al. [58], where powdered Azadirachta indica seeds were added to distilled water at different concentrations (23.8, $122.0,410.0$ and $1,410.0 \mathrm{mg} / 100 \mathrm{~mL}$ ). The results showed that the aqueous extracts could reduce the survival period of Aphis gossypii in a dose-dependent manner, with the higher concentration reducing the life expectancy of the insects from 17.4 to 2.5 days. Other works have also proved the great insecticide effect of Azadirachta indica extracts. HernándezCastro et al. [59], showed the efficiency of aqueous extract $10 \% w / v(10 \mathrm{~g}$ of plant material per $100 \mathrm{~mL}$ of water) of unpeeled Azadirachta indica seed in repelling the aphid Aphis nerii from feeding on papaya plants (Carica papaya L.) sprayed with the plant extract. In addition, the aphid mortality after $24 \mathrm{~h}$ at the extract-sprayed plants was higher by $27 \%$ when compared to the control (only water-sprayed plants). Another work [60] also demonstrated the insecticidal properties of Azadirachta indica aqueous extract, being effective in lowering the numbers of Aphis gossypii after a $72 \mathrm{~h}$ period. In Hossain and Haque's work [61], the water extract of Azadirachta indica seeds $(10 \% \mathrm{v} / \mathrm{w})$ proved to be effective in protecting chickpea (Cicer arietinum L.) seeds against the pulse beetle Callosobruchus chinensis, causing, after a seven days treatment, a significant decrease in the number of laid eggs per 100 seeds $(22 \pm 1.32)$, in the number of adult insects $(41 \pm 1.60)$ and in the infestation percentage (14.61\%) when compared with the control (94.33 \pm 1.97 eggs; $190 \pm 2.28$ adult insects; infestation percentage $=63.57 \%$ ). The same study also showed that other 10 plant water extracts were effective in decreasing these parameters, but none as good as the Azadirachta indica extract.

In a recent study [62], ten aqueous plant extracts $(10 \% w / v$, i.e., $100 \mathrm{~g}$ of plant powder per litre of water) were evaluated regarding their insecticide potential against Spodoptera frugiperda larvae. The plants extracts were from Azadirachta indica, Aloe vera (L.) Burm.f., Cymbopogon citratus (DC.) Stapf, Lantana camara L., Lippia javanica, Nicotiana tabacum, Ocimum basilicum L., Trichilia emetica Vahl, Tephrosia vogelii and Vernonia amygdalina. The most effective extracts were Azadirachta indica, Cymbopogon citratus, Lippia javanica, Nicotiana tabacum and Ocimum basilicum, which caused at least 50\% mortality. Despite the interesting outcomes, the authors presented the results as a graphic which does not allow for an accurate reading of numerical values, in addition to not using a reference insecticide as positive control to allow for comparison of results.

The corn earworm (Helicoverpa zea) and the fall armyworm (Spodoptera frugiperda) were used to test the insecticidal potential of Peumus boldus Molina aqueous extract at concentrations ranging from $0.25 \%$ to $8.0 \% \mathrm{v} / \mathrm{v}$ [63]. After 7 days of diet, the $8.0 \%$ concentration 
extract proved to be the most effective against the pests, causing a mortality of $30.0 \pm 7.2 \%$ against Helicoverpa zea while Spodoptera frugiperda exhibited greater sensitivity to the extract with a mortality of $75.0 \pm 6.5 \%$.

The fumigant toxicity of Allium sativum L. aqueous extract ( $w / v$ at 1:1 ratio) against adults and larvae of Tribolium castaneum was assessed [64]. The results determined that the $\mathrm{LC}_{50}$ values for adults at $24 \mathrm{~h}$ and $48 \mathrm{~h}$ after exposure were of $127.90 \mu \mathrm{L} / \mathrm{L}$ air and $90.8 \mu \mathrm{L} / \mathrm{L}$ air and for larvae they were, respectively, $267.37 \mu \mathrm{L} / \mathrm{L}$ air and $145.8 \mu \mathrm{L} / \mathrm{L}$ air. Furthermore, repellent activity was also evaluated regarding the adults of Tribolium castaneum. A concentration of $2.13 \mu \mathrm{L} / \mathrm{cm}^{2}$ provided a repellence of $95 \pm 7.07 \%$ two hours after exposure. Despite the interesting results, the authors chose to present data in an unconventional way. Conversions for more common units (e.g., $\mu \mathrm{g} / \mathrm{mL}$ ) should have been made to facilitate the reader to make conclusions and be able to compare the results obtained with other similar works.

Aqueous extracts of Saponaria officinalis L. roots (0.2 to $1.9 \% w / v)$ were evaluated regarding their acaricidal effect towards Tetranychus urticae and the results showed that they affected the development stages of the pest in a dose-dependent manner [65]. Adults revealed the lowest sensitivity $\left(\mathrm{LC}_{50}=1.18 \% w / v\right)$, while eggs were the most sensitive $\left(\mathrm{LC}_{50}=0.31 \% w / v\right)$. Furthermore, oviposition was also affected by the different extract concentrations, with a $\mathrm{LC}_{50}$ value established at $0.91 \% w / v$ concentration.

Amoabeng and colleagues [66] presented a study in which the insecticide potential of nine water-detergent extracts (Ageratum conyzoides (L.) L., Capsicum annuum (syn. Capsicum frutescens), Chromolaena odorata (L.) R.M.King \& H.Rob., Jatropha curcas L., Nicotiana tabacum, Ocimum gratissimum, Ricinus communis L., Senna sophera (syn. Cassia sophera) and Synedrella nodiflora (L.) Gaertn. was assessed against both cabbage (Brassica oleracea) pests, the cabbage aphid (Brevicoryne brassicae) and the diamondback moth (Plutella xylostella). All plant extracts ( $3 \mathrm{~g}$ of plant per $100 \mathrm{~mL}$ of tap water resulting in $3 \% \mathrm{w} / \mathrm{v}$ final concentration with $0.1 \%$ Sunligth ${ }^{\circledR}$ detergent) demonstrated to be effective in reducing the insect number of both pests in field cage and open field experiments, presenting results similar to the synthetic insecticide $\mathrm{Attack}^{\circledR}$ (emamectin benzoate) used as control at $1.5 \mathrm{~mL} / \mathrm{L}$. In some cases, the plant extracts matched the effectiveness of the control insecticide, such as Ageratum conyzoides and Chromolaena odorata against Plutella xylostella (100\% number reduction) and Senna sophera, Jatropha curcas, Nicotiana tabacum, Ricinus communis and Synedrella nodiflora against Brevicoryne brassicae (infestation score $=0$ ). Furthermore, it should be mentioned that the plant extracts were much less toxic than the synthetic insecticide to the natural enemies of Brevicoryne brassicae and Plutella xylostella present in the study site, i.e., hoverflies, ladybirds and spiders, causing a smaller impact in the trophic chain.

Brevicoryne brassicae populations were also successfully controlled in an open field study [67] using a water-soap plant extract. An aqueous solution ( $5 \%$ concentration $w / v)$ of powdered Melia azedarach L. seeds was prepared with $0.1 \% w / v$ of soap powder to be sprayed across selected cabbage crop plots. Throughout a six-week treatment period a proportionately increased overall percentage reduction in Brevicoryne brassicae populations was verified, from $19.06 \%$ in the first week to $86.5 \%$ in the last week of the study. Although populations of Brevicoryne brassicae's natural enemy Coccinella septempunctata (i.e., ladybirds) were also reduced, these differences were not statistically significant $(p>0.05)$. Thus, the authors claim that Melia azedarach aqueous extract showed effective aphicide activity, while being safe to natural enemies of Brevicoryne brassicae.

Kestenholz and colleagues [68] investigated, in lab and in the field, the possible insecticide action of Senna sophera (syn. Cassia sophera) cold- and hot-water leaf extracts $(12.5 \% w / v)$, protecting stored Vigna unguiculata (L.) Walp. against Callosobruchus maculatus and Sitophilus oryzae infestations. It was demonstrated that the Senna sophera hot-water extract was more effective in reducing the numbers of Callosobruchus maculatus than the cold-water extract. Regarding Sitophilus oryzae, it appears that the insect mortality was unaffected by the Senna sophera extracts since the number of insects was higher in the jars with the extract treated grains than in the control jar with untreated grains. 
A field study [69] ascertained if the aqueous extracts of leaves and seeds from three plants (i.e., Allium sativum, Swertia chirata Buch.-Ham. ex Wall. and Swietenia mahagoni (L.) Jacq.) could grant insecticide protection to a cucumber (Cucumis sativus L.) field crop. All three extracts ( $100 \mathrm{~g}$ of plant material per litre of distilled water) were effective in protecting Cucumis sativus plants against different pests over a 2-month period, with Swertia chirata showing the best results with an average of $1.67 \pm 0.18$ leaves attacked, while the control (untreated plants) presented an average of $4.66 \pm 0.33$ leaves attacked.

Another field study [70] assessed the insecticide effects of a seven-day treatment of aqueous extracts at 5\% w/v (50 mg of plant per litre of water) of rhizomes of Zingiber officinale Roscoe and leaves of Anthemis cotula L., Artemisia annua L., Datura stramonium L. and Juglans regia L., against Mythimna separata present on oats (Avena sativa L.) crops. After the treatment period, all studied plants reported mortality over $65 \%$ against the pest, with Artemisia annua being the most active, presenting a mortality rate of $84.59 \%$, almost as good as the insecticide of reference Dichlorvos $76 \mathrm{EC}$ (at concentration of $0.076 \%$ ) that presented a mortality rate of $89.34 \%$.

In another field study [71], the effectiveness of Allium sativum (50 mg of plant material per millilitre of distilled water) and Capsicum annuum (syn. Capsicum frutescens) aqueous extracts (70 mg of plant material per millilitre of distilled water) in the management of the major pests (Brevicoryne brassicae, Hellula undalis, Plutella xylostella and Trichoplusia ni) of cabbage (Brassica oleracea) was assessed. After a treatment of four weeks, the results show that both extracts were effective in lowering the population number of all pests, with Brevicoryne brassicae being the most affected by the Allium sativum aqueous extract (reduction of 42.05\%) and Hellula undalis being the most affected by the Capsicum annuum aqueous extract (reduction of $55.94 \%$ ). For term of comparison, the control insecticide Attack ${ }^{\circledR}$ (emamectin benzoate at $2.5 \mathrm{~mL} / \mathrm{L}$ ) was also effective against all pest species, causing a reduction of $70.83 \%$ against Brevicoryne brassicae and of $60.06 \%$ against Hellula undalis.

In a field study [72], the number of cacao mirids (Sahlbergella singularis) were controlled using aqueous extracts obtained from the seeds of Azadirachta indica and Cascabela thevetia (L.) Lippold (syn. Thevetia peruviana (Pers.) K.Schum.), being as effective in reducing the insects in the field as the positive control Actara ${ }^{\circledR} 25$ WG (a benchmark insecticide). Over a period of 5 months both extracts, prepared using $14.7 \mathrm{~g}$ of plant per litre of water were applied over the cacao trees at 15 days intervals and the commercial insecticide was applied, as recommended, at concentration of $0.26 \mathrm{~g} / \mathrm{L}$ once a month. Water, the negative control, was also applied once a month. The results show a decrease in the average number of mirids on each tree over the study period, which was similar for the two extracts (Azadirachta indica: from $5.67 \pm 0.99$ to $1.98 \pm 0.14$; Cascabela thevetia: from $5.33 \pm 0.33$ to $1.21 \pm 0.11$ ) and for the reference insecticide (from $4.83 \pm 0.70$ to $1.67 \pm 0.13$ ). For term of comparison, the results of the negative control increased from $6.33 \pm 1.14$ to $8.95 \pm 1.18$. To achieve comparable effectiveness, the application of the aqueous extracts needs to be twice as frequent as the application of the insecticide, but the authors suggest the adoption of their protocol by farmers for pest control in cacao plantations since it provides similar results while being more environmentally friendly, less risky for human health and cheaper [72]. Although this study is interesting, the authors do not provide enough information to convert the extract preparation data into a dry extract concentration, making it impossible to compare with other studies in which the applied concentration is the extract mass by volume and not plant mass by volume.

Fite et al. [73] carried out a very complete field study. They found that the administration of the aqueous extracts of Azadirachta indica or Millettia ferruginea (Hochst.) Baker, individually $(5 \% w / v$, i.e., $5 \mathrm{~kg}$ of plant material in $100 \mathrm{~L}$ of water) or combined $(2.5 \% w / v$ of each aqueous extract), was effective in lowering the numbers of the pest Helicoverpa armigera in a chickpea crop field, while not causing damage to the chickpea plants and increasing the grain yield. The authors suggest that farmers should spray their crops with the mentioned aqueous extracts twice with 15 days intervals between applications, starting on the 61st day after planting, for maximum results in controlling Helicoverpa armigera 
infestations. It can be highlighted that the extracts exhibit similar activity to the insecticide deltamethrin ( $25 \mathrm{~g} / \mathrm{L}$ applied at recommended dose of $250 \mathrm{~mL} / \mathrm{ha}$ ) used as control (in the second application, the mean of larvae per plant before the treatment with combined aqueous extracts was $2.6 \pm 0.80$ and for the insecticide $2.8 \pm 0.64$, while 3 days after the treatment the means were of $0.73 \pm 0.11$ and $0.93 \pm 0.23$, respectively. In addition, the same study also found that the ethanolic extract of Azadirachta indica could be a viable pest control option since it was equally effective as the aqueous extracts or the insecticide (on the second application, the larvae/plant mean value before the treatment with ethanolic extract was $2.13 \pm 0.41$ decreasing to $0.86 \pm 0.113$ days after the treatment).

In a recent field study [74] aqueous extracts of five plants (Capsicum annuum, Carica papaya, Lantana camara, Nicotiana tabacum and Tagetes minuta) were investigated regarding their efficacy in controlling the population of Aphis gossypii present at an okra (Abelmoschus esculentus (L.) Moench) plantation over a four-month period. A visual scoring rating from 0 to 5 (where 0 meant no aphid presence and 5 meant presence of large continuous colonies) was used to determine the degree of aphid infestation. All plant extracts exerted better action against the pest than the reference insecticide mercaptothion. Better results were obtained at the second month, with Carica papaya presenting the best insecticide action with a score of 0.05 , followed closely by Tagetes minuta (0.06). The remaining plants scored 0.09 (Nicotiana tabacum), 0.12 (Lantana camara) and 0.16 (Capsicum annuum), while the control insecticide scored 0.93. Despite the interesting and promising results obtained by the diverse plant extracts, the study is faulty due to the lack of robustness and reliability in the data presented, since the used system for determination of the degree of aphid infestation (scores from 0 to 5 ) is prone to the subjectivity of those who are collecting the data. A more rigours and precise approach (e.g., counting the number of individuals) would have provided more assurance to extrapolate conclusions for comparison with other works.

\subsection{Ethanolic Extracts}

One of the few published works that uses the Yponomeuta malinellus plague as a target is the Ertürk and colleagues work [75]. In this study, an 8-day assay demonstrated the antifeedant activity exerted over 3-4 $4^{\text {th }}$ instar larvae of Yponomeuta malinellus by ethanolic extracts derived from six different plants (flowers, leaves and stems combined) 1:5 ratio (50 g powder plant material: solvent): i.e., Achillea coarctata Poir., Arum italicum Mill., Buxus sempervirens L., Liquidambar orientalis Mill., Tanacetum vulgare L. and Ocimum basilicum. Liquidambar orientalis provided the highest antifeedant effect with a coefficient of deterrence of $80.90 \%$, followed by Tanacetum vulgare (46.12\%) and Buxus sempervirens (40.11\%). Unfortunately, this work loses impact because it is lacking a reference insecticide as control to allow for better comparison with other published results and better evaluation of its potential as bio-insecticides.

The ethanolic extracts $(0.05 \% w / w)$ of leaves and stems from four Psychotria species, i.e., Psychotria capitata Ruiz \& Pav., Psychotria goyazensis Müll.Arg., Psychotria hoffmannseggiana (Willd. ex Schult.) Müll.Arg. and Psychotria prunifolia (Kunth) Steyerm., proved to be very effective against the pests Sitophilus zeamais and Spodoptera frugiperda. Sitophilus zeamais was very sensitive to the tested extracts, with a mortality rate of $100 \%$ after 3 days of contact with both leaves and stem extracts of Psychotria prunifolia, with leaves extract of Psychotria capitata and with stem extract of Psychotria hoffmannseggiana. Regarding Spodoptera frugiperda, the mortality caused by the leaves and stems extracts ranged from $80.00 \%$ to $95.83 \%$ at the end of an 11-day assay [76].

Spodoptera frugiperda was also the target species of a study aiming to assess the insecticide properties of the ethanolic extract of Euphorbia pulcherrima Willd. ex Klotzsch leaves [77]. Larvae of Spodoptera frugiperda were fed for 12 days an artificial liquid diet containing 0.5 or $1 \%(w / v)$ concentrations of the extract, resulting in impaired development of the larvae. Larval stage was increased by $19.657 \pm 0.712$ days with $0.5 \%$ concentration extract, while simultaneous reducing by $40 \%$ the larval weight in both cases. Larval mortality caused by $0.5 \%$ and $1 \%$ extracts was of, respectively, $24 \%$ and $26 \%$. In addition, the $1 \%$ 
extract also affected Spodoptera frugiperda fertility, leading to a reduced number of the pest eggs. This study reveals a very active extract since it is one of the studies with the lowest applied concentration with significant effect, unfortunately it lacks the use of a reference insecticide, thus the true value of these extracts as bio-insecticides and the comparisons with other similar works are diminished.

The ethanolic extracts of Tagetes erecta flower and leaf also demonstrated to affect Spodoptera frugiperda development once incorporated on their diet $(500 \mathrm{ppm})$ [78]. The larval weight was reduced after a 14-day diet period, with untreated larvae weighing on average $0.3140 \pm 0.1161 \mathrm{~g}$, while larvae with leaf extract diet weighed on average $0.0746 \pm 0.0089 \mathrm{~g}$. In addition, flower extracts were responsible for the highest rate of Spodoptera frugiperda mortality in the assay (i.e., $88 \%$ ).

A different work also evaluated the insecticide potential of Tagetes erecta [79]. The ethanolic extract of its flowers was tested against the stored crop insect pest Tribolium castaneum at larvae and adult stages. The $\mathrm{LC}_{50}$ for the $1^{\text {st }}$ instar larvae was of $31.86 \mu \mathrm{g} / \mathrm{cm}^{2}$ at $72 \mathrm{~h}$ and for the adult stage was of $149.34 \mu \mathrm{g} / \mathrm{cm}^{2}$ at $72 \mathrm{~h}$. The authors opted to present these units since they were calculated by measuring the dry weight of the extract present in $1 \mathrm{~mL}$ that was applied into the Petri dish divided by the surface area of the respective Petri dishes. This is slightly problematic because it does not allow comparison with different works.

Azadirachta indica ethanolic extract was the best of nine extracts whose effectiveness in protecting chickpea seeds against the pulse beetle Callosobruchus chinensis was evaluated [61]. This extract at $10 \% \mathrm{v} / \mathrm{w}$ concentration caused, after a seven days treatment, the decrease in the number of adult insects $(25.67 \pm 1.40)$, laid eggs per 100 seeds $(15.67 \pm 1.19)$ and infestation percentage $(9.24 \%)$ when compared with the control $(190 \pm 2.28 ; 94.33 \pm 1.97$ and $63.57 \%$, respectively).

An extensive work carried out by Chermenskaya et al. [80] analysed the insecticide and feeding deterrent potential of 139 ethanolic extracts $(1 \% w / v$ concentration) of different morphological parts of 123 plants, applied over young bean leaves (Phaseolus vulgaris), against three agricultural pests: western flower thrips (Frankliniella occidentalis), grain aphid (Shizaphis graminum) and two-spotted spider mite (Tetranychus urticae). Frankliniella occidentalis proved to be highly tolerant to the plant extracts, with only 12 plants showing some activity. The extracts of the aerial parts of Plantago major L. and Silene sussamyrica Lazkov presented the best activities, causing reduction in the numbers of the species after five days of treatment by $41.9 \%$ and $50.2 \%$, respectively. In contrast, the other pest species tested were way more susceptible to the plant extracts. The numbers of Shizaphis graminum were reduced by 69 plant extracts, with 8 of them showing high insecticidal activity (over $80 \%$ mortality). Ungernia sewerzowii (Regel) B. Fedtsch. (root extract), Anabasis aphylla L. (twigs extract) and Ferula foetida (Bunge) Regel. (root extract) caused a mortality of 89.1, 95.1 and $100 \%$, respectively, $24 \mathrm{~h}$ after leaves treatment, and proved to be the best extracts against Shizaphis graminum. Regarding Tetranychus urticae, 75 plant extracts were effective in lowering their numbers over seven days of treatment with 7 plant extracts showing high insecticidal activity (over $80 \%$ mortality). The most active extracts were those of the roots of Convolvulus krauseanus Regel. and Schmalh. (95.6\% mortality) and the leaves of Ailanthus altissima (Mill.) Swingle (97.4\% mortality). In addition, the feeding deterrent results carried out with the extracts that presented efficacy over $80 \%$ showed that the Ailanthus altissima, Allium obliquum L. and Vinca erecta Regel \& Schmalh. plant extracts were 100\% effective in deterring the spider mites, while the Anabasis aphylla twig extract was the most effective (81.1\%) in deterring the grain aphid. Extracts from seeds and twigs of Anabasis aphylla, roots of Aconitum soongaricum (Regel) Stapf and aerial parts of Prangos lipskyi Korovin proved to be the most effective, with over $90 \%$ of feeding deterring against western flower thrips. A flaw in this article is that, despite the numerous extracts tested that allow to obtain several valuable results, the authors could have standardized the presentation of results, e.g., in detailed tables, and not have the results spread over several tables, graphics and scattered along the article, which makes it difficult to understand the data obtained. 
Syzygium cumini (L.) Skeels ethanolic extract at concentrations of 75, 150 and $300 \mu \mathrm{g} / \mathrm{mL}$ were also tested to control the population of Tetranychus urticae. The obtained mortality rates were $35.00 \pm 0.31 \%, 85.00 \pm 0.64 \%$ and $100.00 \pm 0.00 \%$, while the $\mathrm{LC}_{50}$ value was established at $98 \mu \mathrm{g} / \mathrm{mL}$ [81]. It should be noted that the insecticide effects observed in this study were obtained using much lower concentrations (about 100 times lower) than what is generally reported by other studies. It would have been extremely relevant to report a result obtained under the same experimental conditions using a pesticide of reference in order to validate this level of activity. Numa and colleagues [82] also used Tetranychus urticae as target species on the evaluation of the potential insecticidal effect of the ethanolic extract of Cnidoscolus aconitifolius (Mill.) I.M.Johnst. leaves. The mortality and oviposition of individuals were recorded over a $72 \mathrm{~h}$ period after exposure to the extracts at various concentrations (10 to $2000 \mu \mathrm{g} / \mathrm{mL}$ ), being notorious an increased mortality and a reduced fertility in a dose-dependent manner. The $\mathrm{LC}_{50}$ of 24,48 and $72 \mathrm{~h}$ were ascertained at $1223.637 \pm 47.85 \mu \mathrm{g} / \mathrm{mL}, 990.37 \pm 44.24 \mu \mathrm{g} / \mathrm{mL}$ and $901.25 \pm 41.54 \mu \mathrm{g} / \mathrm{mL}$, respectively.

Zhang et al. [83] conducted a study evaluating the insecticide potential of powdered tubers of an unusual plant (Pinellia ternata (Thunb.) Makino) against the beet armyworm Spodoptera exigua, a target also little used. They reported that the ethanol extract inhibited feeding from $43.07 \%$ to $86.78 \%$ at concentrations ranging between 12.5 and $100 \mathrm{mg} / \mathrm{mL}$, with a $\mathrm{LC}_{50}$ of $43.594 \mathrm{mg} / \mathrm{mL}$ after $48 \mathrm{~h}$ of treatment. In addition, for the same concentration range, oviposition deterrent activity was between $39.69 \%$ and $78.34 \%$.

In addition to aqueous extracts (see previous section), ethanolic extracts have also been tested to combat the Plutella xylostella pest. Silva and colleagues [84] evaluated the effect of various ethanolic extracts from leaves and stems mainly of Croton species (i.e., Croton jacobinensis Baill., Mallotus rhamnifolius (Willd.) Müll.Arg. (syn. Croton rhamnifolius Willd.) and Croton sellowii Baill.) against the diamondback moth (Plutella xylostella). All extracts proved to be toxic $\left(\mathrm{LC}_{50}\right.$ values of 14.95 to $1252.00 \mu \mathrm{g} / \mathrm{mL}$ ) with the leaf extract from Mallotus rhamnifolius demonstrating the greatest toxicity $\left(\mathrm{LC}_{50}=14.95 \mu \mathrm{g} / \mathrm{mL}\right)$, followed by its stem extract $\left(\mathrm{LC}_{50}=42.40 \mu \mathrm{g} / \mathrm{mL}\right)$. If the authors had added a control with a reference insecticide the study would have gain extra scientific power, but this was not the case.

Cabbage aphid Brevicoryne brassicae is a very common target in bio-pesticides studies. A recent work [85] evaluated the ethanolic leaf extracts (2.5 to $20 \mathrm{mg} / \mathrm{mL})$ of Artemisia argyi H.Lév. \& Vaniot, Cannabis sativa L. (syn. Cannabis indica Lam.) and Citrullus colocynthis (L.) Schrad. effects against the pest Brevicoryne brassicae. The toxicity results demonstrated that the Artemisia argyi extract was the most active $\left(\mathrm{LC}_{50}\right.$ value of $\left.3.91 \mathrm{mg} / \mathrm{mL}\right)$, followed by Citrullus colocynthis and Cannabis sativa with, respectively, $\mathrm{LC}_{50}$ values of $6.26 \mathrm{mg} / \mathrm{mL}$ and $10.04 \mathrm{mg} / \mathrm{mL}$.

In addition to the most relevant studies discussed above, other studies involving other target pests and aqueous and ethanolic extracts from other plants are published and deserve to be mentioned in this review. Many of these studies involve simpler experimental designs, especially the activity shown by the plant under study and the target species used. In order to provide a more clear and direct reading, the following table (Table 1), alphabetically organized by the taxonomic name of the evaluated plant species, summarizes the most relevant information regarding the aqueous and ethanolic plant extracts with potential as new bio-insecticides. Two additional columns were added to clarify the plant part used and the extraction processes involved in each reference, providing sufficient information to allow for easy replication of the results obtained by anyone who seeks this kind of knowledge to overcome pest issues. 
Table 1. Plant species mentioned in literature with potential to be effective bio-insecticides, according to their aqueous and/or ethanolic extracts pesticide properties.

\begin{tabular}{|c|c|c|c|c|c|c|}
\hline Plant Species & Extract & Part of the Plant Used & Extract Preparation & Target Insect Species & Activity * & References \\
\hline Achillea coarctata Poir. & Ethanolic & $\begin{array}{l}\text { Flowers; } \\
\text { Leaves; } \\
\text { Stems }\end{array}$ & $\begin{array}{c}\text { Maceration (50 g DW + EtOH at } \\
1: 5 \text { ratio) }\end{array}$ & Yponomeuta malinellus & Deterrence index $=24.65 \%$ & [75] \\
\hline $\begin{array}{l}\text { Aconitum soongaricum } \\
\text { (Regel) Stapf }\end{array}$ & $\begin{array}{l}\text { Aqueous- } \\
\text { ethanolic }\end{array}$ & Roots & $\begin{array}{c}\text { Maceration }(30 \mathrm{~g} \mathrm{DW}+300 \mathrm{~mL} \text { EtOH}) \\
\text { aqueous emulsions at a concentration of } \\
1 \%\end{array}$ & Frankliniella occidentalis & Deterrence index over $90 \%$ & [80] \\
\hline Ageratum conyzoides (L.) L. & Aqueous & Leaves & Maceration (30 g FW + $1 \mathrm{~L}$ tap water) & $\begin{array}{l}\text { Brevicoryne brassicae; } \\
\text { Plutella xylostella }\end{array}$ & $\begin{array}{c}100 \pm 0.00 \% \text { P. xylostella number } \\
\text { reduction }(3 \% w / v)\end{array}$ & [66] \\
\hline $\begin{array}{l}\text { Ailanthus altissima (Mill.) } \\
\text { Swingle }\end{array}$ & $\begin{array}{l}\text { Aqueous- } \\
\text { ethanolic }\end{array}$ & Leaves & $\begin{array}{c}\text { Maceration }(30 \mathrm{~g} \mathrm{DW}+300 \mathrm{~mL} \text { EtOH), } \\
\text { aqueous emulsions at a concentration of } \\
1 \%\end{array}$ & Tetranychus urticae & $\begin{array}{l}97.4 \% \text { T. urticae number reduction after } \\
7 \text { days of treatment }\end{array}$ & [80] \\
\hline Allium obliquum $\mathrm{L}$. & $\begin{array}{l}\text { Aqueous- } \\
\text { ethanolic }\end{array}$ & Whole plant & $\begin{array}{c}\text { Maceration }(30 \mathrm{~g} \mathrm{DW}+300 \mathrm{~mL} \text { EtOH), } \\
\text { aqueous emulsions at a concentration of } \\
1 \%\end{array}$ & Tetranychus urticae & $100 \%$ deterrence index over T. urticae & [80] \\
\hline Allium sativum $\mathrm{L}$. & Aqueous & Bulb & $\begin{array}{c}\text { Maceration }\left(\mathrm{FW}+\mathrm{H}_{2} \mathrm{O} \text { at } 1: 1 \text { ratio) [64]; }\right. \\
\text { Maceration }\left(100 \mathrm{~g} \mathrm{DW}+1 \mathrm{~L} \mathrm{H} \mathrm{H}_{2} \mathrm{O}\right)[69] \\
\text { Maceration }\left(100 \mathrm{~g} \mathrm{FW}+0.5 \mathrm{~L} \mathrm{H}_{2} \mathrm{O}\right) \\
\mathrm{H}_{2} \mathrm{O} \text { added until } 2 \mathrm{~L}[71]\end{array}$ & $\begin{array}{c}\text { Acalymma vittatum [69]; } \\
\text { Brevicoryne brassicae [71]; } \\
\text { Hellula undalis [71]; } \\
\text { Plutella xylostella [71]; } \\
\text { Polyphagotarsonemus latus [69]; } \\
\text { Raphidopalpa foveicollis [69]; } \\
\text { Tribolium castaneum [64]; } \\
\text { Trichoplusia ni [71] }\end{array}$ & $\begin{array}{c}\mathrm{LC}_{50} \text { against } T \text {. castaneum at } \\
48 \mathrm{~h}=90.8 \mu \mathrm{L} / \mathrm{L} \text { air }[64] ; \\
\text { Average treated crop leaves } \\
\text { attacked }=4.11 \pm 0.77 \text { (Average of leaves } \\
\text { attacked in untreated crop }=4.66 \pm 0.33 \text { ) } \\
{[69] ;} \\
\text { B. brassicae reduction of } 42.05 \% \\
\text { (Control insecticide emamectin benzoate } \\
\text { at } 2.5 \mathrm{~mL} / \mathrm{L}=\text { reduction of } 70.83 \% \text { ) [71] }\end{array}$ & {$[64,69,71]$} \\
\hline Ammi majus L. & Ethanolic & Seeds & $\begin{array}{l}\text { Maceration }(250 \mathrm{~g} \mathrm{DW}+500 \mathrm{~mL} \text { EtOH } \\
\text { for } 72 \mathrm{~h})\end{array}$ & Agrotis ipsilon & $\begin{array}{l}\text { Antifeedant index after } 24 \mathrm{~h} \text { feeding on } \\
5 \% \text { extract-treated leaves }=56.4 \%\end{array}$ & [86] \\
\hline Anabasis aphylla $\mathrm{L}$. & $\begin{array}{l}\text { Aqueous- } \\
\text { ethanolic }\end{array}$ & $\begin{array}{l}\text { Seeds; } \\
\text { Twigs }\end{array}$ & $\begin{array}{c}\text { Maceration }(30 \mathrm{~g} \mathrm{DW}+300 \mathrm{~mL} \text { EtOH), } \\
\text { aqueous emulsions at a concentration of } \\
1 \%\end{array}$ & Shizaphis graminum & $\begin{array}{l}95.1 \% \text { S. graminum number reduction } \\
\text { after } 24 \text { h of treatment (twigs extract) }\end{array}$ & [80] \\
\hline Annona squamosa $\mathrm{L}$. & $\begin{array}{l}\text { Aqueous; } \\
\text { Ethanolic }\end{array}$ & Seeds & Maceration $\underset{\text { EtOH })}{\left(10 \mathrm{~g} \mathrm{DW}+100 \mathrm{~mL} \mathrm{H} \mathrm{H}_{2} \mathrm{O} \text { or }\right.}$ & Callosobruchus chinensis & $\begin{array}{c}\text { Aqueous: } \\
\text { C. chinensis infestation } \\
\text { percentage }=23.77 \% \text { after } 7 \text { days of } 10 \% \\
\text { extract treatment; } \\
\text { Ethanol: } \\
\text { C. chinensis infestation } \\
\text { extract treatment } \\
\text { percentage }=19.55 \% \text { days of } 10 \% \\
\text { (Control: } \text { C. chinensis infestation } \\
\text { percentage }=63.57 \% \text { after } 7 \text { days } \\
\text { treatment) }\end{array}$ & [61] \\
\hline
\end{tabular}


Table 1. Cont.

\begin{tabular}{|c|c|c|c|c|c|c|}
\hline Plant Species & Extract & Part of the Plant Used & Extract Preparation & Target Insect Species & Activity* & References \\
\hline Anthemis cotula $\mathrm{L}$. & Aqueous & Leaves & Maceration $\left(50 \mathrm{mg} \mathrm{FW}+1000 \mathrm{~mL} \mathrm{H} \mathrm{H}_{2} \mathrm{O}\right)$ & Mythimna separata & $\begin{array}{c}\text { Mortality rate }=80.71 \% \\
(\text { Control: Dichlorvos } 76 \mathrm{EC}(0.076 \%) \\
\text { mortality rate }=89.34 \% .)\end{array}$ & [70] \\
\hline $\begin{array}{l}\text { Aphanamixis polystachya } \\
\text { (Wall.) R.Parker }\end{array}$ & $\begin{array}{l}\text { Aqueous; } \\
\text { Ethanolic }\end{array}$ & Seeds & $\begin{array}{c}\text { Maceration }\left(10 \mathrm{~g} \mathrm{DW}+100 \mathrm{~mL} \mathrm{H} \mathrm{H}_{2} \mathrm{O} \text { or }\right. \\
\text { EtOH })\end{array}$ & Callosobruchus chinensis & $\begin{array}{c}\text { Aqueous: } \\
\text { C. chinensis infestation } \\
\text { percentage = } 21.55 \% \text { after } 7 \text { days of } 10 \% \\
\text { extract treatment; } \\
\text { Ethanol: } \\
\text { C. chinensis infestation } \\
\text { percentage }=32.62 \% \text { after } 7 \text { days of } 10 \% \\
\text { extract treatment } \\
\text { (Control: } \text { C. } \text { chinensis infestation } \\
\text { percentage }=63.57 \% \text { after } 7 \text { days of } \\
\text { treatment) }\end{array}$ & [61] \\
\hline Apium graveolens $\mathrm{L}$. & Ethanolic & Seeds & $\begin{array}{c}\text { Maceration }(250 \mathrm{~g} \mathrm{DW}+500 \mathrm{~mL} \mathrm{EtOH} \\
\text { for } 72 \mathrm{~h})\end{array}$ & Agrotis ipsilon & $\begin{array}{c}\text { Antifeedant index after } 24 \mathrm{~h} \text { feeding on } \\
5 \% \text { extract-treated leaves }=56.6 \% \\
\text { Mortality rate }=84.59 \%\end{array}$ & [86] \\
\hline Artemisia annua L. & Aqueous & Leaves & Maceration $\left(50 \mathrm{mg} F W+1000 \mathrm{~mL} \mathrm{H}_{2} \mathrm{O}\right)$ & Mythimna separata & $\begin{array}{c}\text { (Control: Dichlorvos } 76 \text { EC }(0.076 \%) \\
\text { mortality rate }=89.34 \% .)\end{array}$ & [70] \\
\hline $\begin{array}{c}\text { Artemisia argyi H.Lév. \& } \\
\text { Vaniot }\end{array}$ & Ethanolic & Leaves & $\begin{array}{c}\text { Maceration }(100 \mathrm{~g} \text { DW }+3 \times 400 \mathrm{~mL} \\
\text { EtOH for } 72 \mathrm{~h} \text { each) }\end{array}$ & Brevicoryne brassicae & $\mathrm{LC}_{50}=3.91 \mathrm{mg} / \mathrm{mL}$ & [85] \\
\hline $\begin{array}{l}\text { Atraphaxis toktogulicum } \\
\text { (Lazkov) T.M. Schust. \& } \\
\text { Reveal (syn. Polygonum } \\
\text { toktogulicum Lazkov) }\end{array}$ & $\begin{array}{l}\text { Aqueous- } \\
\text { ethanolic }\end{array}$ & Root & $\begin{array}{c}\text { Maceration (30 g DW }+300 \mathrm{~mL} \mathrm{EtOH}) \text {, } \\
\text { aqueous emulsions at a concentration of } \\
1 \%\end{array}$ & Shizaphis graminum & $\begin{array}{l}84.0 \% \text { S. graminum number reduction } \\
\text { after } 24 \mathrm{~h} \text { of treatment }\end{array}$ & [80] \\
\hline
\end{tabular}


Table 1. Cont.

Target Insect Species

\section{Aqueous:}

Maceration ( 23.8 to $1410.0 \mathrm{mg}$ DW + 100 $\left.\mathrm{mL} \mathrm{H} \mathrm{H}_{2} \mathrm{O}\right)$ [58];

Infusion $\left(25 \mathrm{~g} \mathrm{FW}+250 \mathrm{~mL} \mathrm{H}_{2} \mathrm{O}\right)$ [59]

Maceration $\left(1 \mathrm{~kg} \mathrm{DW}+1.76 \mathrm{~L} \mathrm{H}_{2} \mathrm{O}\right)[60]$

Maceration $\left(10 \mathrm{~g} \mathrm{DW}+100 \mathrm{~mL} \mathrm{H}_{2} \mathrm{O}\right)$

$\begin{array}{lc}\text { Aqueous } & \text { Leaves } \\ {[58-62,72,73] ;} & {[62] ;} \\ \text { Ethanolic } & \text { Seeds } \\ {[61,73]} & {[58-61,72,73]}\end{array}$

Aphis gossypii $[58,60]$ Aphis nerii [59] Helicoverpa armígera [73]; Sahlbergella singularis [72] [61];

Maceration (100 g DW + $1 \mathrm{~L} \mathrm{H}_{2} \mathrm{O}+0.1 \%$ soap) [62]

Maceration $\left(250 \mathrm{~g} \mathrm{DW}+17 \mathrm{~L} \mathrm{H}_{2} \mathrm{O}+10 \mathrm{~g}\right.$ soap) [72];

Maceration (5 kg DW + $100 \mathrm{~L} \mathrm{H}_{2} \mathrm{O}$ ) [73] Ethanolic:

Maceration $(10 \mathrm{~g}$ DW $+100 \mathrm{~mL}$ EtOH [61];

Maceration (100 g DW + $100 \mathrm{~mL}$ EtOH $)$ [73]

\section{Activity}

References

A. gossypii life expectancy reduced from 17.4 to 2.5 days at $14.1 \mathrm{mg} / \mathrm{mL}$ [58]; $27 \%$ higher mortality after $24 \mathrm{~h}$ when compared to the control (water-sprayed plants) [59];

A. gossypii numbers lowered by $\approx 80 \%$ after $72 \mathrm{~h} \mathrm{[60]}$

Aqueous:

C. chinensis infestation

percentage $=14.61 \%$ after 7 days of $10 \%$

$$
\text { extract treatment; }
$$

$$
\text { Ethanolic: }
$$

\section{C. chinensis infestation}

percentage $=9.24 \%$ after 7 days of $10 \%$ extract treatment

(Control: C. chinensis infestation percentage $=63.57 \%$ after 7 days of

Callosobruchus chinensis [61];

Spodoptera frugiperda [62] treatment) [61];

S. frugiperda larvae mortality over $50 \%$ at $10 \%$ extract [62];

S. singularis average number decreased after 5-month extract application at $14.7 \mathrm{~g} / \mathrm{L}$ from $5.33 \pm 0.33$ to $1.21 \pm 0.11$ (Control: Actara ${ }^{\circledR} 25$ WG at $0.26 \mathrm{~g} / \mathrm{L}$ from $4.83 \pm 0.70$ to $1.67 \pm 0.13$; untreated plants from $6.33 \pm 1.14$ to $8.95 \pm 1.18)[72]$ Aqueous:

larvae/plant mean value before the treatment $=2.53 \pm 0.64$ and 3 days after the treatment $=0.93 \pm 0.30$;

$$
\text { Ethanol: }
$$

larvae/plant mean value before the treatment $=2.13 \pm 0.41$ and 3 days after the treatment $=0.86 \pm 0.11$

(Control insecticide deltamethrin $25 \mathrm{~g} / \mathrm{L}$ applied at recommended dose of

$250 \mathrm{~mL} / \mathrm{ha}=2.8 \pm 0.64$ before treatment and $0.93 \pm 0.23$ after 3 days) [73] 
Table 1. Cont

\begin{tabular}{|c|c|c|c|c|c|c|}
\hline Plant Species & Extract & Part of the Plant Used & Extract Preparation & Target Insect Species & Activity* & References \\
\hline $\begin{array}{l}\text { Brugmansia suaveolens } \\
\text { (Humb. \& Bonpl. ex Willd.) } \\
\text { Bercht. \& J.Presl }\end{array}$ & Aqueous & $\begin{array}{l}\text { Flowers; } \\
\text { Leaves }\end{array}$ & $\begin{array}{l}\text { Infusion }\left(\mathrm{FW}+\mathrm{H}_{2} \mathrm{O}\right) \text { and Maceration } \\
\quad\left(\mathrm{DW}+\mathrm{H}_{2} \mathrm{O}\right) \text { both at } 5 \% w / v\end{array}$ & Brevicoryne brassicae & $\begin{array}{l}\text { B. brassicae average survival at } 10 \% \\
\text { concentration (leaves) }=2.1 \text { days } \\
(\text { Control }=6.2 \text { days })\end{array}$ & [55] \\
\hline Buxus sempervirens L. & Ethanolic & $\begin{array}{l}\text { Flowers; } \\
\text { Leaves; } \\
\text { Stems }\end{array}$ & $\begin{array}{c}\text { Maceration }(50 \mathrm{~g} \mathrm{DW}+\mathrm{EtOH} \text { at } 1: 5 \\
\text { ratio) }\end{array}$ & Yponomeuta malinellus & Deterrence index $=40.11 \%$ & [75] \\
\hline $\begin{array}{l}\text { Cannabis sativa L. (syn. } \\
\text { Cannabis indica Lam.) }\end{array}$ & Ethanolic & Leaves & $\begin{array}{l}\text { Maceration }(100 \mathrm{~g} \mathrm{DW}+3 \times 400 \mathrm{~mL} \\
\text { EtOH for } 72 \mathrm{~h} \text { each) }\end{array}$ & Brevicoryne brassicae & $\mathrm{LC}_{50}=10.04 \mathrm{mg} / \mathrm{mL}$ & [85] \\
\hline $\begin{array}{c}\text { Capsicum annuum L. [74] } \\
\text { (syn. Capsicum frutescens L. } \\
[66,71])\end{array}$ & $\begin{array}{c}\text { Aqueous } \\
{[66,71,74]} \\
\text { Aqueous- } \\
\text { ethanolic } \\
{[80]}\end{array}$ & $\begin{array}{c}\text { Fruits } \\
{[66,71,74]} \\
\text { Leaves } \\
{[80]}\end{array}$ & $\begin{array}{c}\text { Maceration (30 g FW + } 1 \mathrm{~L} \text { tap water) } \\
{[66] ;} \\
\text { Maceration }\left(140 \mathrm{~g} \mathrm{FW}+0.5 \mathrm{~L} \mathrm{H}_{2} \mathrm{O}\right) \\
\mathrm{H}_{2} \mathrm{O} \text { added until } 2 \mathrm{~L}[71] ; \\
\text { Maceration }\left(300 \mathrm{~g} \mathrm{FW}+20 \mathrm{~L} \mathrm{H}_{2} \mathrm{O}\right)[74] \\
\text { Maceration }(30 \mathrm{~g} \mathrm{DW}+300 \mathrm{~mL} \text { EtOH }) \\
\text { aqueous emulsions at a concentration of } \\
1 \% \text { [80] }\end{array}$ & $\begin{array}{c}\text { Aphis gossypii [74]; } \\
\text { Brevicoryne brassicae [66,71]; } \\
\text { Hellula undalis [71]; } \\
\text { Plutella xylostella [71]; } \\
\text { Tetranychus urticae [80]; } \\
\text { Trichoplusia ni [71] }\end{array}$ & $\begin{array}{c}93 \pm 0.06 \% \text { P. xylostella number } \\
\text { reduction (3\% w/v concentration) [66]; } \\
\text { H. undalis reduction of } 45.94 \% \\
\text { (Control insecticide emamectin benzoate } \\
\text { at } 2.5 \mathrm{~mL} / \mathrm{L}=\text { reduction of } 60.06 \%)[71] \\
\text { A. gossypii infestation score at } 2 \mathrm{nd} \\
\text { month }=0.16 \\
\text { (Control insecticide mercaptothion } \\
\text { infestation score at } 2 \text { nd month }=0.93 \text { ) } \\
\text { [74]; } \\
\text { 85.6\% T. urticae number reduction after } \\
7 \text { days of treatment [80] }\end{array}$ & {$[66,71,74,80]$} \\
\hline Carica papaya L. & Aqueous & Leaves & Maceration (300 g DW + $20 \mathrm{~L} \mathrm{H}_{2} \mathrm{O}$ ) & Aphis gossypii & $\begin{array}{l}\text { Infestation score at } 2 \text { nd month }=0.05 \\
\text { (Control insecticide mercaptothion } \\
\text { infestation score at } 2 \text { nd month }=0.93 \text { ) }\end{array}$ & [74] \\
\hline $\begin{array}{l}\text { Cascabela thevetia (L.) } \\
\text { Lippold (syn. Thevetia } \\
\text { peruviana (Pers.) K.Schum.) }\end{array}$ & Aqueous & Seeds & $\begin{array}{l}\text { Maceration }\left(250 \mathrm{~g} \mathrm{DW}+17 \mathrm{~L} \mathrm{H}_{2} \mathrm{O}+10 \mathrm{~g}\right. \\
\text { soap) }\end{array}$ & Sahlbergella singularis & $\begin{array}{l}\text { S. singularis average number decreased } \\
\text { after } 5 \text {-month extract application at } \\
14.7 \mathrm{~g} / \mathrm{L} \text { from } 5.33 \pm 0.33 \text { to } 1.21 \pm 0.11 \\
\left(\text { Control: Actara }{ }^{\circledR} 25 \mathrm{WG} \text { at } 0.26 \mathrm{~g} / \mathrm{L}\right. \\
\text { caused decrease from } 4.83 \pm 0.70 \text { to } \\
1.67 \pm 0.13 \text {; untreated plants increased } \\
\text { average number from } 6.33 \pm 1.14 \text { to } \\
8.95 \pm 1.18)\end{array}$ & [72] \\
\hline $\begin{array}{l}\text { Catharanthus roseus (L.) } \\
\text { G.Don (syn. Vinca rosea L.) }\end{array}$ & Ethanolic & Aerial & $\begin{array}{l}\text { Maceration }(250 \mathrm{~g} \mathrm{DW}+500 \mathrm{~mL} \text { EtOH } \\
\text { for } 72 \mathrm{~h})\end{array}$ & Agrotis ipsilon & $\begin{array}{c}\text { Antifeedant index after } 24 \mathrm{~h} \text { feeding on } \\
5 \% \text { extract-treated leaves }=72.2 \%\end{array}$ & [86] \\
\hline
\end{tabular}


Table 1. Cont

\begin{tabular}{|c|c|c|c|c|c|c|}
\hline Plant Species & Extract & Part of the Plant Used & Extract Preparation & Target Insect Species & Activity* & References \\
\hline $\begin{array}{l}\text { Cestrum elegans (Brongn. ex } \\
\text { Neumann) Schltdl. }\end{array}$ & Ethanolic & Aerial & $\begin{array}{l}\text { Maceration }(250 \mathrm{~g} \mathrm{DW}+500 \mathrm{~mL} \mathrm{EtOH} \\
\text { for } 72 \mathrm{~h})\end{array}$ & Agrotis ipsilon & $\begin{array}{c}\text { Antifeedant index after } 24 \mathrm{~h} \text { feeding on } \\
5 \% \text { extract-treated leaves }=59.2 \%\end{array}$ & [86] \\
\hline $\begin{array}{l}\text { Chromolaena odorata (L.) } \\
\text { R.M.King \& H.Rob. }\end{array}$ & Aqueous & Leaves & Maceration (30 g FW + 1 L tap water) & $\begin{array}{l}\text { Brevicoryne brassicae; } \\
\text { Plutella xylostella }\end{array}$ & $\begin{array}{c}100 \pm 0.00 \% \text { P. xylostella number } \\
\text { reduction }(3 \% w / v \text { concentration })\end{array}$ & [66] \\
\hline $\begin{array}{l}\text { Cnidoscolus aconitifolius } \\
\text { (Mill.) I.M.Johnst. }\end{array}$ & Ethanolic & Leaves & Maceration $(\mathrm{DW}+\mathrm{EtOH})$ & Tetranychus urticae & $72 \mathrm{~h} \mathrm{LC}_{50}=901.25 \pm 41.54 \mu \mathrm{g} / \mathrm{mL}$ & [82] \\
\hline $\begin{array}{l}\text { Convolvulus krauseanus } \\
\text { Regel. \& Schmalh. }\end{array}$ & $\begin{array}{l}\text { Aqueous- } \\
\text { ethanolic }\end{array}$ & Roots & $\begin{array}{c}\text { Maceration }(30 \mathrm{~g} \mathrm{DW}+300 \mathrm{~mL} \text { EtOH }) \text {, } \\
\text { aqueous emulsions at a concentration of } \\
1 \%\end{array}$ & Tetranychus urticae & $\begin{array}{l}95.6 \% \text { T. urticae number reduction after } \\
7 \text { days of treatment }\end{array}$ & [80] \\
\hline Coriandrum sativum L. & Aqueous & Leaves & $\begin{array}{l}\text { Infusion }\left(\mathrm{FW}+\mathrm{H}_{2} \mathrm{O}\right) \text { and Maceration } \\
\left(\mathrm{DW}+\mathrm{H}_{2} \mathrm{O}\right)\end{array}$ & $\begin{array}{l}\text { Brevicoryne brassicae; } \\
\text { Myzus persicae }\end{array}$ & $\begin{array}{l}\text { B. brassicae and } M \text {. persicae survival rate } \\
\text { at } 10 \% \text { concentration after } 72 \mathrm{~h}=0 \% \\
(\text { Control insecticide }=0 \%)\end{array}$ & [56] \\
\hline Crotalaria juncea $\mathrm{L}$. & $\begin{array}{l}\text { Aqueous; } \\
\text { Ethanolic }\end{array}$ & Seeds & $\begin{array}{c}\text { Maceration }\left(10 \mathrm{~g} \mathrm{DW}+100 \mathrm{~mL} \mathrm{H} \mathrm{H}_{2} \mathrm{O} \text { or }\right. \\
\text { EtOH })\end{array}$ & Callosobruchus chinensis & $\begin{array}{c}\text { Aqueous: } \\
\text { C. chinensis infestation } \\
\text { percentage = } 30.58 \% \text { after } 7 \text { days of } 10 \% \\
\text { extract treatment; } \\
\text { Ethanol: } \\
\text { C. chinensis infestation } \\
\text { percentage }=25.77 \% \text { after } 7 \text { days of } 10 \% \\
\text { extract treatment } \\
\text { (Control: } \text { C. chinensis infestation } \\
\text { percentage }=63.57 \% \text { after } 7 \text { days of } \\
\text { treatment) }\end{array}$ & [61] \\
\hline Croton jacobinensis Baill. & Ethanolic & $\begin{array}{l}\text { Leaves; } \\
\text { Stem }\end{array}$ & Maceration (DW + EtOH) & Plutella xylostella & $\mathrm{LC}_{50}$ stem extract $=116.21 \mu \mathrm{g} / \mathrm{mL}$ & [84] \\
\hline Croton sellowii Baill. & Ethanolic & $\begin{array}{l}\text { Leaves; } \\
\text { Stem }\end{array}$ & Maceration $(\mathrm{DW}+\mathrm{EtOH})$ & Plutella xylostella & $\mathrm{LC}_{50}$ leaves extract $=80.1 .36 \mu \mathrm{g} / \mathrm{mL}$ & [84] \\
\hline $\begin{array}{l}\text { Cymbopogon citratus (DC.) } \\
\text { Stapf }\end{array}$ & Aqueous & Leaves & $\begin{array}{c}\text { Maceration }\left(100 \mathrm{~g} \mathrm{DW}+1 \mathrm{~L} \mathrm{H}_{2} \mathrm{O}+0.1 \%\right. \\
\text { soap) }\end{array}$ & Spodoptera frugiperda & Larvae mortality over $50 \%$ at $10 \%$ extract & [62] \\
\hline Datura stramonium $\mathrm{L}$. & Aqueous & Leaves & Maceration (50 mg FW + 1000 mL H ${ }_{2} \mathrm{O}$ ) & Mythimna separata & $\begin{array}{c}\text { Mortality rate }=79.17 \% \\
(\text { Control: Dichlorvos 76 EC }(0.076 \%) \\
\text { mortality rate }=89.34 \% .)\end{array}$ & [70] \\
\hline $\begin{array}{l}\text { Dodonaea viscosa subsp. } \\
\text { angustifolia (L.f.) J.G.West } \\
\text { (syn. Dodonaea angustifolia } \\
\text { L.f.) }\end{array}$ & Aqueous & Leaves & Maceration $\left(1 \mathrm{~kg}+\mathrm{H}_{2} \mathrm{O}\right)$ & Earias vittella & $\begin{array}{c}\text { Damage crop dropped from } 48.2 \% \text { to } \\
26.0 \% \text { after } 10 \% \text { extract application } \\
\text { (Control insecticide } \\
\text { endosulfan = damage crop from } 46.7 \% \\
\text { to } 28.1 \% \text { ) }\end{array}$ & [87] \\
\hline
\end{tabular}


Table 1. Cont

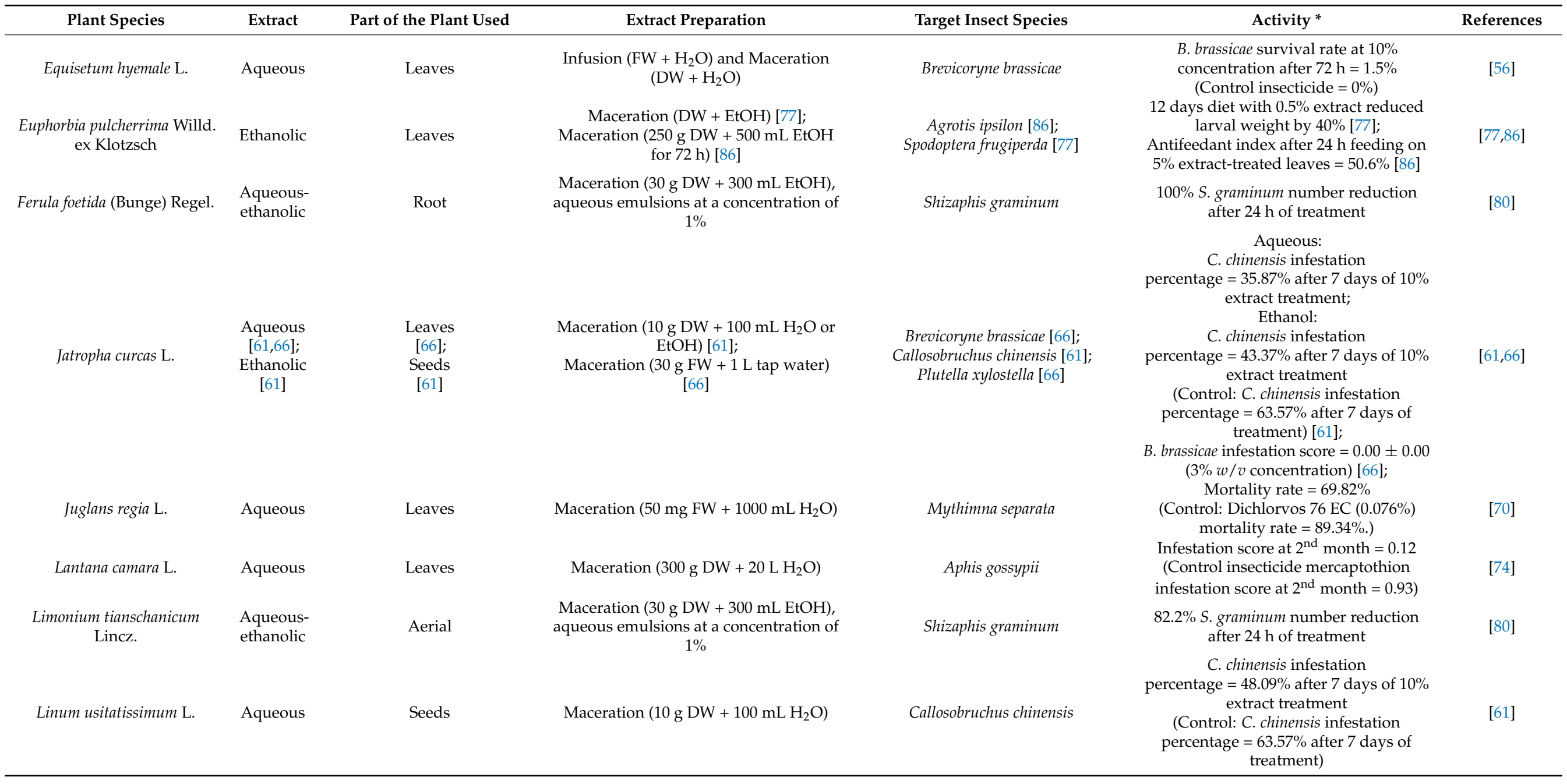


Table 1. Cont

\begin{tabular}{|c|c|c|c|c|c|c|}
\hline Plant Species & Extract & Part of the Plant Used & Extract Preparation & Target Insect Species & Activity* & References \\
\hline $\begin{array}{l}\text { Lippia javanica (Burm.f.) } \\
\text { Spreng. }\end{array}$ & Aqueous & Leaves & $\begin{array}{c}\text { Maceration (DW }+\mathrm{H}_{2} \mathrm{O} ; 1 \% \text { and } 10 \% \\
w / v)[54] ; \\
\text { Maceration (100 g DW }+1 \mathrm{~L} \mathrm{H}_{2} \mathrm{O}+0.1 \% \\
\text { soap) [62] }\end{array}$ & $\begin{array}{c}\text { Aphis fabae [54]; } \\
\text { Epicauta albovittata [54]; } \\
\text { Epicauta limbatipennis [54]; } \\
\text { Ootheca mutabilis [54]; } \\
\text { Ootheca bennigseni [54]; } \\
\text { Spodoptera frugiperda [62] }\end{array}$ & $\begin{array}{l}\text { Index of plant damage by O. mutabilis } \\
\text { and Ootheca bennigseni of } 0.30 \\
\text { (Controls: pesticide }=0.39 \text { and untreated } \\
\text { plants }=2.01 \text { ) [54]; } \\
\text { S. frugiperda larvae mortality over } 50 \% \text { at } \\
\quad 10 \% \text { extract }[62]\end{array}$ & {$[54,62]$} \\
\hline Liquidambar orientalis Mill. & Ethanolic & $\begin{array}{l}\text { Flowers; } \\
\text { Leaves; } \\
\text { Stems }\end{array}$ & $\begin{array}{c}\text { Maceration }(50 \mathrm{~g} \mathrm{DW} \\
\text { ratio) }\end{array}$ & Yponomeuta malinellus & Deterrence index $=80.90 \%$ & [75] \\
\hline Luffa cylindrica (L.) M.Roem. & Ethanolic & Aerial & $\begin{array}{c}\text { Maceration }(250 \mathrm{~g} \mathrm{DW}+500 \mathrm{~mL} \text { EtOH } \\
\text { for } 72 \mathrm{~h})\end{array}$ & Agrotis ipsilon & $\begin{array}{l}\text { Antifeedant index after } 24 \mathrm{~h} \text { feeding on } \\
5 \% \text { extract-treated leaves }=68.2 \%\end{array}$ & [86] \\
\hline $\begin{array}{l}\text { Mallotus rhamnifolius (Willd.) } \\
\text { Müll.Arg. (syn. Croton } \\
\text { rhamnifolius Willd.) }\end{array}$ & Ethanolic & $\begin{array}{l}\text { Leaves; } \\
\text { Stem }\end{array}$ & Maceration $(\mathrm{DW}+\mathrm{EtOH})$ & Plutella xylostella & $\mathrm{LC}_{50}$ leaves extract $=14.95 \mu \mathrm{g} / \mathrm{mL}$ & [84] \\
\hline Melia azedarach $\mathrm{L}$. & $\begin{array}{l}\text { Aqueous } \\
\text { [67]; } \\
\text { Ethano- } \\
\text { lic } \\
{[86]}\end{array}$ & $\begin{array}{l}\text { Leaves } \\
\text { [86]; } \\
\text { Seeds } \\
\text { [67] }\end{array}$ & $\begin{array}{c}\text { Maceration (5 g DW + } 100 \mathrm{~mL} \text { tap water) } \\
{[67]} \\
\text { Maceration ( } 250 \mathrm{~g} \mathrm{DW}+500 \mathrm{~mL} \text { EtOH } \\
\text { for } 72 \mathrm{~h})[86]\end{array}$ & $\begin{array}{c}\text { Agrotis ipsilon [86]; } \\
\text { Brevicoryne brassicae [67]; }\end{array}$ & $\begin{array}{c}\text { 86.5\% B. brassicae number reduction ( } 5 \% \\
w / v \text { concentration) [67]; } \\
\text { Antifeedant index after } 24 \mathrm{~h} \text { feeding on } \\
5 \% \text { extract-treated leaves }=80.3 \%[86]\end{array}$ & {$[67,86]$} \\
\hline Mentha arvensis $\mathrm{L}$ & $\begin{array}{l}\text { Aqueous- } \\
\text { ethanolic }\end{array}$ & Leaves & $\begin{array}{c}\text { Maceration }(30 \mathrm{~g} \mathrm{DW}+300 \mathrm{~mL} \text { EtOH), } \\
\text { aqueous emulsions at a concentration of } \\
1 \%\end{array}$ & Tetranychus urticae & $\begin{array}{c}86.9 \% \text { T. urticae number reduction after } \\
7 \text { days of treatment }\end{array}$ & [80] \\
\hline
\end{tabular}


Table 1. Cont.

Plant Species

B. brassicae and $M$. persicae survival rate at $10 \%$ after $72 \mathrm{~h}=0 \%$

(Control insecticide $=0 \%$ ) [56] Aqueous:

C. chinensis infestation

percentage $=24.51 \%$ after 7 days of $10 \%$ extract treatment;

$$
\text { Ethanol: }
$$

Infusion $\left(\mathrm{FW}+\mathrm{H}_{2} \mathrm{O}\right)$ and Maceration $\left(\mathrm{DW}+\mathrm{H}_{2} \mathrm{O}\right)[56]$;

Maceration $\left(10 \mathrm{~g} \mathrm{DW}+100 \mathrm{~mL} \mathrm{H}_{2} \mathrm{O}\right.$ or

$$
\text { EtOH) [61] }
$$

66,74];

Leaves [6

Maceration (30ap) [62];
Aphis gossypii [74]; Brevicoryne brassicae $[56,66]$; Callosobruchus chinensis [61]; Myzus persicae [56] Plutella xylostella [66]; Spodoptera frugiperda [62]

$$
\text { [66] }
$$

Maceration (300 g DW + $20 \mathrm{~L} \mathrm{H}_{2} \mathrm{O}$ ) [74]

Infusion $\left(\mathrm{FW}+\mathrm{H}_{2} \mathrm{O}\right.$ ) and Maceration

$\left(\mathrm{DW}+\mathrm{H}_{2} \mathrm{O}\right)$ both at $5 \% w / v$

Nicotiana tabacum var. virginica (C. Agardh) Comes

Ocimum basilicum L.

Ethanolic

Howers;

Leaves

Flowers;

Leaves:

Aqueous

$[56,66]$;

Ocimum gratissimum $\mathrm{L}$.

Aqueous-

[88]

Leaves

Origanum vulgare $\mathrm{L}$.
Maceration $(50 \mathrm{~g}$ DW + EtOH at 1:5 ratio)

Infusion $\left(\mathrm{FW}+\mathrm{H}_{2} \mathrm{O}\right)$ and Maceration $\left(\mathrm{DW}+\mathrm{H}_{2} \mathrm{O}\right)[56]$

Maceration (30 g FW + 1 L tap water) [66];

Maceration (100 g DW + $300 \mathrm{~mL}$ EtOH) $1 \%$ to $4 \%$ concentration $w / v$ [88] Maceration (30 g DW + $300 \mathrm{~mL}$ EtOH) aqueous emulsions at a concentration of dissolved in $\mathrm{H}_{2} \mathrm{O}$ to prepare solutions of 
Table 1. Cont

\begin{tabular}{|c|c|c|c|c|c|c|}
\hline Plant Species & Extract & Part of the Plant Used & Extract Preparation & Target Insect Species & Activity * & References \\
\hline Papaver rhoeas L. & $\begin{array}{l}\text { Aqueous- } \\
\text { ethanolic }\end{array}$ & Aerial & $\begin{array}{c}\text { Maceration (30 g DW }+300 \mathrm{~mL} \mathrm{EtOH}) \text {, } \\
\text { aqueous emulsions at a concentration of } \\
1 \%\end{array}$ & Tetranychus urticae & $\begin{array}{l}89.7 \% \text { T. urticae number reduction after } \\
7 \text { days of treatment }\end{array}$ & [80] \\
\hline $\begin{array}{l}\text { Persicaria hydropiper (L.) } \\
\text { Delarbre (syn. Polygonum } \\
\text { hydropiper L.) }\end{array}$ & $\begin{array}{l}\text { Aqueous; } \\
\text { Ethanolic }\end{array}$ & Seeds & $\begin{array}{c}\text { Maceration }\left(10 \mathrm{~g} \mathrm{DW}+100 \mathrm{~mL} \mathrm{H} \mathrm{H}_{2} \mathrm{O} \text { or }\right. \\
\text { EtOH })\end{array}$ & Callosobruchus chinensis & $\begin{array}{c}\text { Aqueous: } \\
\text { C. chinensis infestation } \\
\text { percentage }=23.86 \% \text { after } 7 \text { days of } 10 \% \\
\text { extract treatment; } \\
\text { Ethanol: } \\
\text { C. chinensis infestation } \\
\text { percentage }=37.62 \% \text { after } 7 \text { days of } 10 \% \\
\text { extract treatment } \\
(\text { Control: } \text { C. chinensis infestation } \\
\text { percentage }=63.57 \% \text { after } 7 \text { days of } \\
\text { treatment })\end{array}$ & [61] \\
\hline Peumus boldus Molina & Aqueous & Leaves & Maceration $\left(10 \mathrm{~g} \mathrm{DW}+100 \mathrm{~mL} \mathrm{H}_{2} \mathrm{O}\right)$ & $\begin{array}{c}\text { Helicoverpa zea; } \\
\text { Spodoptera frugiperda }\end{array}$ & $\begin{array}{l}\text { S. frugiperda after } 7 \text { days of diet with } \\
8.0 \% \text { extract presented } \mathrm{LC}_{50} \text { of } \\
2.31 \mathrm{~mL} / \mathrm{kg}\end{array}$ & [63] \\
\hline $\begin{array}{l}\text { Pinellia ternata (Thunb.) } \\
\text { Makino }\end{array}$ & Ethanolic & Tubers & Maceration (50 g DW + 1 L EtOH) & Spodoptera exigua & $\mathrm{LC}_{50}$ at $48 \mathrm{~h}$ of $43.594 \mathrm{mg} / \mathrm{mL}$ & [83] \\
\hline Pistacia vera $\mathrm{L}$. & Ethanolic & Leaves & $\begin{array}{c}\text { Maceration }(250 \mathrm{~g} \mathrm{DW}+500 \mathrm{~mL} \mathrm{EtOH} \\
\text { for } 72 \mathrm{~h})\end{array}$ & Agrotis ipsilon & $\begin{array}{l}\text { Antifeedant index after } 24 \mathrm{~h} \text { feeding on } \\
5 \% \text { extract-treated leaves }=65.0 \%\end{array}$ & [86] \\
\hline Prangos lipskyi Korovin & $\begin{array}{l}\text { Aqueous- } \\
\text { ethanolic }\end{array}$ & Aerial & $\begin{array}{c}\text { Maceration }(30 \mathrm{~g} \mathrm{DW}+300 \mathrm{~mL} \text { EtOH), } \\
\text { aqueous emulsions at a concentration of } \\
1 \%\end{array}$ & Tetranychus urticae & $\begin{array}{l}\text { 86.1\% T. urticae number reduction after } \\
7 \text { days of treatment }\end{array}$ & [80] \\
\hline $\begin{array}{c}\text { Psychotria capitata Ruiz \& } \\
\text { Pav. }\end{array}$ & Ethanolic & $\begin{array}{l}\text { Leaves; } \\
\text { Stems }\end{array}$ & Maceration $(\mathrm{FW}+\mathrm{EtOH})$ & $\begin{array}{l}\text { Sitophilus zeamais; } \\
\text { Spodoptera frugiperda }\end{array}$ & $\begin{array}{l}\text { Mortality rate of } S \text {. zeamais after } 3 \text { days } \\
(0.05 \%)=100 \% \text { (leaves extract) }\end{array}$ & {$[76]$} \\
\hline $\begin{array}{l}\text { Psychotria goyazensis } \\
\text { Müll.Arg. }\end{array}$ & Ethanolic & $\begin{array}{l}\text { Leaves; } \\
\text { Stems }\end{array}$ & Maceration $(\mathrm{FW}+\mathrm{EtOH})$ & $\begin{array}{l}\text { Sitophilus zeamais; } \\
\text { Spodoptera frugiperda }\end{array}$ & $\begin{array}{l}\text { Mortality rate of } S \text {. frugiperda after } 11 \\
(0.05 \%) \text { days }=95.83 \% \text { (stem extract) }\end{array}$ & {$[76]$} \\
\hline $\begin{array}{l}\text { Psychotria hoffmannseggiana } \\
\text { (Willd. ex Schult.) Müll.Arg. }\end{array}$ & Ethanolic & $\begin{array}{l}\text { Leaves; } \\
\text { Stems }\end{array}$ & Maceration (FW + EtOH) & $\begin{array}{l}\text { Sitophilus zeamais; } \\
\text { Spodoptera frugiperda }\end{array}$ & $\begin{array}{l}\text { Mortality rate of S. zeamais after } 3 \text { days } \\
\quad(0.05 \%)=100 \% \text { (stem extract) }\end{array}$ & [76] \\
\hline $\begin{array}{l}\text { Psychotria prunifolia (Kunth) } \\
\text { Steyerm. }\end{array}$ & Ethanolic & $\begin{array}{l}\text { Leaves; } \\
\text { Stems }\end{array}$ & Maceration $(\mathrm{FW}+\mathrm{EtOH})$ & $\begin{array}{l}\text { Sitophilus zeamais; } \\
\text { Spodoptera frugiperda }\end{array}$ & $\begin{array}{l}\text { Mortality rate of S. zeamais after } 3 \text { days } \\
(0.05 \%)=100 \% \text { (both extracts) }\end{array}$ & [76] \\
\hline
\end{tabular}


Table 1. Cont.

Plant Species

Extract

Part of the Plant Used

Extract Preparation

\section{Maceration (10 g DW + $100 \mathrm{~mL} \mathrm{H}_{2} \mathrm{O}$ or EtOH) [61] \\ Maceration (30 g FW + 1 L tap water)}

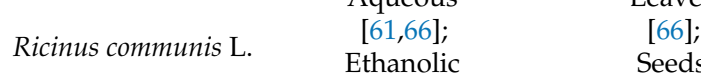

[61]

[66]

$$
\text { Maceration }\left(\mathrm{DW}+\mathrm{H}_{2} \mathrm{O}\right)
$$

Maceration (100, 80, 60, 30 or $15 \mathrm{~g}$ DW +

$$
1 \mathrm{~L} \text { tap water) }
$$

\section{Saponaria officinalis L.}

Aqueous

Roots

Senna sophera (L.) Roxb.

(syn. Cassia sophera L.)

Aqueous

Leaves

Sida acuta Burm.f. Aqueous-

Leaves

Silene sussamyrica Lazkov

Aqueous-

ethanolic

Aerial

Fruits;

Leaves

Solanum aculeatissimum Jacq.

Aqueous

Flowers;

Solanum bonariense L. (syn

Solanum fastigiatum var.

Aqueous fastigiatum)

\section{FW $+1 \mathrm{~L}$ tap water)}

$$
\text { [66]; }
$$

Infusion and Maceration (100 g DW +

$$
800 \mathrm{~mL} \mathrm{H}_{2} \mathrm{O} \text { ) [68] }
$$

Maceration (100 g DW + $300 \mathrm{~mL}$ EtOH) dissolved in $\mathrm{H}_{2} \mathrm{O}$ to prepare solutions of

$$
1 \% \text { to } 4 \% \text { concentration } w / v
$$

aqueous emulsions at a concentration of $1 \%$

Infusion $\left(\mathrm{FW}+\mathrm{H}_{2} \mathrm{O}\right)$ and Maceration $\left(\mathrm{DW}+\mathrm{H}_{2} \mathrm{O}\right)$ both at $5 \% w / v$

Infusion $\left(\mathrm{FW}+\mathrm{H}_{2} \mathrm{O}\right)$ and Maceration $\left(\mathrm{DW}+\mathrm{H}_{2} \mathrm{O}\right)$ both at $5 \% \mathrm{w} / v$
Maceration (30 g DW + $300 \mathrm{~mL}$ EtOH),
Target Insect Species

Activity *

$$
\text { Aqueous: }
$$

C. chinensis infestation

percentage $=42.93 \%$ after 7 days of $10 \%$

extract treatment; Ethanol:

Brevicoryne brassicae [66];

Callosobruchus chinensis [61]

Plutella xylostella [66]

percentage $=42.38 \%$ after 7 days of $10 \%$ extract treatment

(Control: C. chinensis infestation percentage $=63.57 \%$ after 7 days of

$$
\text { treatment) [61]; }
$$

B. brassicae infestation score $=0.00 \pm 0.00$ ( $3 \% w / v$ concentration) [66]

Larvae mortality of $63.15 \%$ after 14 days

Spodoptera frugiperda of feeding of treated corn leaves $(1 \%$ $w / v)$

Tetranychus urticae

$\mathrm{LC}_{50}$ for eggs $=0.31 \% w / v$

Brevicoryne brassicae [66]; Callosobruchus maculatus [68] Plutella xylostella [66]

B. brassicae infestation score $=0.00 \pm 0.00$ ( $3 \% w / v$ concentration) [66];

Number of C. maculatus statistically significant reduced when compared with the control $(p<0.05)[68]$

Acanthoscelides obtectus

Mortality rate $(4 \%$ extract $)=31.47 \%$

Frankliniella occidentalis

$50.2 \%$ F. occidentalis number reduction after 5 days of treatment

Brevicoryne brassicae

B. brassicae average survival at $1 \%$ concentration (fruits) $=3.3$ days (Control $=6.2$ days)

B. brassicae average survival at $10 \%$

Brevicoryne brassicae (Control $=6.2$ days) 
Table 1. Cont.

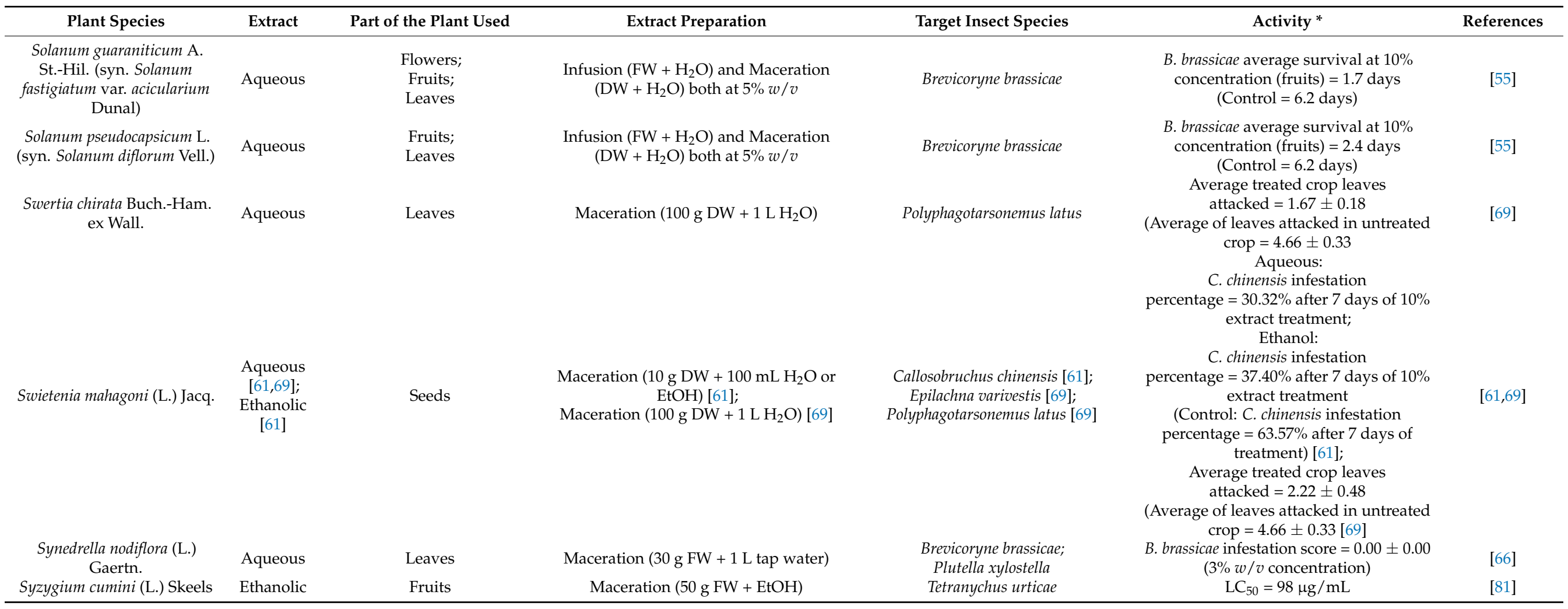


Table 1. Cont.

Plant Species Extract

\section{Part of the Plant Used}

Extract Preparation

int Used

(1)

\section{Flowers}

queous

[61];
Aqueous-

Tagetes erecta $\mathrm{L}$.

Ethanolic

[90];

Ethanolic

$[61,78,79$

90]

$[78,79]$

Leaves

[90]
Maceration $\left(10 \mathrm{~g} \mathrm{DW}+100 \mathrm{~mL} \mathrm{H} \mathrm{H}_{2} \mathrm{O}\right.$ or EtOH) [61];

Maceration (500 g DW + EtOH)[78]; Maceration (1 kg DW + 5 L EtOH) [79];

Maceration (DW + absolute EtOH or $\mathrm{EtOH} / \mathrm{H}_{2} \mathrm{O}(70 / 30)$ at a ratio $w / v$ of 1:10) [90]

\begin{tabular}{|c|c|c|}
\hline Tagetes minuta L. & Aqueous & Leaves \\
\hline $\begin{array}{c}\text { Calisia esculenta (A. St.-Hil.) } \\
\text { Radlk. }\end{array}$ & Aqueous & Seeds \\
\hline $\begin{array}{l}\text { Tanacetum cinerariifolium } \\
\text { (Trevir.) Sch.Bip. (syn. } \\
\text { Pyrethrum cinerariifolium } \\
\text { Trevir.) }\end{array}$ & $\begin{array}{l}\text { Aqueous- } \\
\text { ethanolic }\end{array}$ & Aerial \\
\hline Tanacetum vulgare $\mathrm{L}$. & Ethanolic & $\begin{array}{l}\text { Flowers; } \\
\text { Leaves; } \\
\text { Stems }\end{array}$ \\
\hline Celfairia occidentalis Hook.f. & $\begin{array}{l}\text { Aqueous- } \\
\text { ethanolic }\end{array}$ & Leaves \\
\hline
\end{tabular}

\section{Maceration (300 g DW + $20 \mathrm{~L} \mathrm{H}_{2} \mathrm{O}$ )}

$$
\text { Maceration }\left(\mathrm{DW}+\mathrm{H}_{2} \mathrm{O}\right)
$$

Maceration (30 g DW + $300 \mathrm{~mL}$ EtOH), aqueous emulsions at a concentration of $1 \%$

$$
\underset{\text { ratio) }}{\text { Maceration (50 g DW }}+\text { EtOH at 1:5 }
$$
dissolved in $\mathrm{H}_{2} \mathrm{O}$ to prepare solutions of $1 \%$ to $4 \%$ concentration $w / v$
Maceration (100 g DW + $300 \mathrm{~mL}$ EtOH),

\section{Target Insect Species}

Callosobruchus chinensis [61] Sitophilus zeamais [90]; Spodoptera frugiperda [78] Tribolium castaneum [79]

Aphis gossypii
Spodoptera frugiperda
Shizaphis graminum
Yponomeuta malinellus
Acanthoscelides obtectus

Activity *

$$
\text { Aqueous: }
$$

C. chinensis infestation

percentage $=41.90 \%$ after 7 days of $10 \%$

extract treatmen

Ethanol:

C. chinensis infestation

percentage $=36.98 \%$ after 7 days of $10 \%$ extract treatment

(Control: C. chinensis infestation percentage $=63.57 \%$ after 7 days of

$$
\text { treatment) [61]; }
$$

S. frugiperda mortality rate $=88 \%$ (leaf's extract) [78];

At $72 \mathrm{~h}$ after treatment $\mathrm{LC}_{50}$ of $T$. castaneum larvae $=31.86 \mu \mathrm{g} / \mathrm{cm}^{2}[79]$; Aqueous-ethanolic $\mathrm{LC}_{50}$ against $S$. zeamais $=12.59 \mathrm{mg} / \mathrm{mL}$; Ethanolic $\mathrm{LC}_{50}$ against

S. zeamais $=11.23 \mathrm{mg} / \mathrm{mL}$ [90] Infestation score at $2^{\text {nd }}$ month $=0.06$ (Control insecticide mercaptothion infestation score at $2^{\text {nd }}$ month $=0.93$ ) Larvae mortality of $26.71 \%$ after 14 days of feeding of treated corn leaves $(1 \%$ concentration)

$80.2 \%$ S. graminum number reduction after $24 \mathrm{~h}$ of treatment

References

.

Mortality rate $(4 \%$ extract $)=15.20 \%$ 
Table 1. Cont

\begin{tabular}{|c|c|c|c|c|c|c|}
\hline Plant Species & Extract & Part of the Plant Used & Extract Preparation & Target Insect Species & Activity * & References \\
\hline Tephrosia vogelii Hook.f. & Aqueous & Leaves & $\begin{array}{c}\text { Maceration }\left(\mathrm{DW}+\mathrm{H}_{2} \mathrm{O} ; 1 \% \text { and } 10 \%\right. \\
w / v)\end{array}$ & $\begin{array}{c}\text { Aphis fabae; } \\
\text { Epicauta albovittata; } \\
\text { Epicauta limbatipennis; } \\
\text { Ootheca mutabilis; } \\
\text { Ootheca bennigseni }\end{array}$ & $\begin{array}{l}\text { Index of plant damage by O. mutabilis } \\
\text { and Ootheca bennigseni of } 0.94 \\
\text { (Controls: pesticide }=0.39 \text { and untreated } \\
\text { plants }=2.01 \text { ) }\end{array}$ & [54] \\
\hline $\begin{array}{l}\text { Tithonia diversifolia (Hemsl.) } \\
\text { A.Gray }\end{array}$ & Aqueous & Leaves & $\begin{array}{c}\text { Maceration }\left(\mathrm{DW}+\mathrm{H}_{2} \mathrm{O} ; 1 \% \text { and } 10 \%\right. \\
w / v)\end{array}$ & $\begin{array}{l}\text { Aphis fabae; } \\
\text { Epicauta albovittata; } \\
\text { Epicauta limbatipennis; } \\
\text { Ootheca mutabilis; } \\
\text { Ootheca bennigseni }\end{array}$ & $\begin{array}{l}\text { Index of plant damage by O. mutabilis } \\
\text { and Ootheca bennigseni of } 1.09 \\
\text { (Controls: pesticide }=0.39 \text { and untreated } \\
\text { plants }=2.01)\end{array}$ & [54] \\
\hline $\begin{array}{l}\text { Ungernia sewerzowii (Regel) } \\
\text { B. Fedtsch. }\end{array}$ & $\begin{array}{l}\text { Aqueous- } \\
\text { ethanolic }\end{array}$ & Root & $\begin{array}{c}\text { Maceration ( } 30 \mathrm{~g} \mathrm{DW}+300 \mathrm{~mL} \text { EtOH), } \\
\text { aqueous emulsions at a concentration of } \\
1 \%\end{array}$ & Shizaphis graminum & $\begin{array}{l}89.1 \% \text { S. graminum number reduction } \\
\text { after } 24 \mathrm{~h} \text { of treatment }\end{array}$ & [80] \\
\hline Vernonia amygdalina Delile & $\begin{array}{l}\text { Aqueous } \\
\text { [54]; } \\
\text { Aqueous- } \\
\text { Ethanolic } \\
\quad[88]\end{array}$ & Leaves & $\begin{array}{l}\text { Maceration (DW }+\mathrm{H}_{2} \mathrm{O} ; 1 \% \text { and } 10 \% \\
w / v)[54] ; \\
\text { Maceration }(100 \mathrm{~g} \mathrm{DW}+300 \mathrm{~mL} \text { EtOH), } \\
\text { dissolved in } \mathrm{H}_{2} \mathrm{O} \text { to prepare solutions of } \\
\quad 1 \% \text { to } 4 \% \text { concentration } w / v \text { [88] }\end{array}$ & $\begin{array}{c}\text { Acanthoscelides obtectus [88]; } \\
\text { Aphis fabae [54]; } \\
\text { Epicauta albovittata [54]; } \\
\text { Epicauta limbatipennis [54]; } \\
\text { Ootheca mutabilis [54]; } \\
\text { Ootheca bennigseni [54] }\end{array}$ & $\begin{array}{c}\text { Average insect abundance of } O . \text { mutabilis } \\
\text { and Ootheca bennigseni of } 0.63 \\
\text { (Controls: pesticide }=0.37 \text { and untreated } \\
\text { plants }=2.45) \text { [ } 54] \\
\text { A. obtectus mortality rate }(4 \% \\
\text { extract })=33.60 \%[88]\end{array}$ & {$[54,88]$} \\
\hline $\begin{array}{l}\text { Vinca erecta Regel \& } \\
\text { Schmalh. }\end{array}$ & $\begin{array}{l}\text { Aqueous- } \\
\text { ethanolic }\end{array}$ & Aerial & $\begin{array}{c}\text { Maceration (30 g DW + } 300 \mathrm{~mL} \text { EtOH), } \\
\text { aqueous emulsions at a concentration of } \\
1 \%\end{array}$ & Tetranychus urticae & $100 \%$ deterrence index over T. urticae & [80] \\
\hline $\begin{array}{l}\text { Withania somnifera (L.) } \\
\text { Dunal }\end{array}$ & Ethanolic & Aerial & $\begin{array}{c}\text { Maceration (250 g DW + } 500 \mathrm{~mL} \text { EtOH } \\
\text { for } 72 \mathrm{~h})\end{array}$ & Agrotis ipsilon & $\begin{array}{l}\text { Antifeedant index after } 24 \mathrm{~h} \text { feeding on } \\
5 \% \text { extract-treated leaves }=63.0 \% \\
\text { Mortality rate }=75.64 \%\end{array}$ & [86] \\
\hline Zingiber officinale Roscoe & Aqueous & Rhizomes & Maceration $\left(50 \mathrm{mg} \mathrm{FW}+1000 \mathrm{~mL} \mathrm{H} \mathrm{H}_{2} \mathrm{O}\right)$ & Mythimna separata & $\begin{array}{c}\text { (Control: Dichlorvos 76 EC }(0.076 \%) \\
\text { mortality rate }=89.34 \% .)\end{array}$ & [70] \\
\hline
\end{tabular}

DW-Dry weight; EtOH—Ethanol; FW—Fresh weight; $\mathrm{H}_{2} \mathrm{O}$-Distilled water. ${ }^{*}$ Only the highest level of activity per plant per reference presented. 
The above table (Table 1) addresses 95 plants whose aqueous and/or ethanolic extracts were reported in scientific studies as presenting some sort of insecticide property. Despite the effort to reconcile all the information in the best possible way, to facilitate its reading and to allow conclusions between the different studies, data comparisons are limited by the different and non-convertible units (e.g., plant mass per volume vs. extract mass per volume) that many authors chose to present their results and by the methodologies used in each work.

For instance, 14 different non-comparable categories (some of them with their unique units) could be used to express the insecticide property of an extract throughout the covered studies (i.e., Number of Leaves Damaged, Damage Index, Damage Rate, Life Expectancy, Survival Rate, Mortality Rate, $\mathrm{LC}_{50}$, Infestation Rate, Infestation Score, Insect Number Reduction Rate, Insect Number Reduction, Antifeedant and Deterrence Index, Weight Reduction and Larvae/Plant Ratio). Thus, comparison of results can only be made according to other studies from the same category of insecticide property, e.g., Capsicum annuum aqueous extract caused a reduction of $45.94 \%$ of Hellula undalis population [71] while Ageratum conyzoides caused a 100\% reduction of Plutella xylostella population [66]. Furthermore, different species react in different ways, whereby conclusions should be made with caution regarding the potential of a particular extract from a given plant against a specific pest. Regardless of that, some conclusions can be made analysing Table 1 without impairments and will be discussed in the next section.

\section{Final Considerations and Future Perspectives}

The increasing global demand for food production results in an immense pressure to produce faster and bigger crop yields, leading to an excessive use of synthetic pesticides, from smallholders to big farms, without concerns for the long-term effects. In order to combat the negative consequences of synthetic pesticides use, without jeopardizing agricultural outcome, a search for effective alternatives began in the last decades and is currently ongoing. Plants produce remarkable compounds to overcome the challenges imposed by nature and are seen as the main source of answers to this problem.

Regarding plants used to protect crops in traditional agriculture, several examples can be given with various species being used in different ways, depending on the location. Azadirachta indica and Nicotiana tabacum can be highlighted as two of the plants reported regularly, being vastly rooted in agricultural popular knowledge. Therefore, it is not surprising that both plants belong to the most targeted plants for research in bio-insecticides, with interesting results consolidating their practices in traditional farming knowledge.

The literature analysis of studies that addressed the task of ascertaining the insecticide properties of aqueous and/or ethanolic plant extracts allowed for the identification of 95 plants with reported and validated insecticide activity, having potential to be viable options in the pest management approach, after further studies. From the 95 plants, four can be highlighted as the most researched ones (i.e., Azadirachta indica, Capsicum annuum, Nicotiana tabacum, and Tagetes erecta) with Azadirachta indica being present at 7 different studies with promising results (e.g., aqueous seed extract could reduce the survival period of Aphis gossypii from a life expectancy of 17.4 days to 2.5 days; 3 days of treatment with aqueous seed extract resulted in a lower larvae/plant ratio of Helicoverpa armigera).

To determine the insecticide potential of each extract from each plant, a total of 34 insect species, known for being crop pests, were used in the various works. Brevicoryne brassicae was by far the most targeted species, being tested against the aqueous and/or ethanolic extracts of 23 different plants. Other commonly targeted pests were Plutella xylostella, Spodoptera frugiperda, Callosobruchus chinensis, Tetranychus urticae and Agrotis ipsilon, tested against 14,13,11, 11 and 9 distinct plants, respectively.

Maceration with dried material (usually leaves) plus water or ethanol was the main choice of most authors, with some of them providing detailed information regarding quantities of plant material and solvents used. Unfortunately, in other cases authors are too vague when addressing the extraction method, sticking to just stating "plant 
material soaked in solvent for $24 \mathrm{~h}$ " which is problematic for any reader trying to replicate procedures, compare results and deduce conclusions.

In addition, other plants not included here can also be targeted for future works since they also possess insecticide properties, but their aqueous and/or ethanolic extracts are not yet investigated, i.e., plants with insecticide activities exhibited by other organic extracts $[21,91]$, essential oils $[92,93]$ and pure compounds $[45,94]$. Other plants that should be considered for future research are the ones that proved their insecticide property through other techniques, e.g., powders [95], or against other insects that are not seen as agricultural pests, such as mosquitos [96,97], termites [98,99] and ticks [100,101]. In addition, plants know as companion plants should also be considered since they act many times as repellent for specific insects [20,102]. Furthermore, it should be noted the existence of published studies with interesting results and experimental designs using aqueous and ethanolic plant extracts but obtained through more complex extraction techniques (e.g., soxhlet) that could also be taken into account in the search for new bio-insecticides but that fall out of the scope of this review [103-107].

This review shows that, in addition to the choice of the target plant and pest, most published works do not take into account an integrated vision of bio-insecticides uses. In fact, few are the studies that include variables in their experimental design such as phytotoxicity and effect on plant growth, impact on non-targeted species such as bees and effects on human health through their consumption [52,108]. The evaluation of longterm use of bio-insecticides in the surrounding place is imperative and some form of safety assessment needs to be considered as it could have serious repercussions. Studies carried out with plant extracts of organic solvents that have residual toxicity, such as methanol [109], are not useful in the field as alternatives to the existing environmentally hazardous synthetic pesticides, thus only works with aqueous and/or ethanolic plant extracts should be the norm. In addition, field studies where real farmers learn from real scientists the reasons to change their habits should be prioritized over laboratory ones [110], because despite good results in controlled laboratory conditions, when put into practice on the field by farmers themselves, results may be unpredictable, causing a waste of time and money and the return to the use of synthetic pesticides.

Regardless of the above suggestions to improve research in this subject and ensure better formulations of bio-insecticides, allowing for sufficient persistence of their stability, quality and insecticidal effect, there is still a major obstacle that only delays the adoption of bio-insecticides in the detriment of conventional synthetic insecticides. Probably the biggest impairment is the regulatory environments that changes according to countries legislations [111]. Health and environmental problems caused by insecticides in the past are the common denominators that lead to strict criteria for the registration of new insecticides, e.g., in Europe [112] and in the USA [113]. As defined by European Regulation (EC No. 1107/2009) the adoption of new bio-insecticides based on active substances (pure compounds with, in this case, insecticide properties) and basic substances (i.e., other registered bio-products which may be useful for plant protection) should demonstrate and guarantee that they are not carcinogenic, corrosive or skin sensitisers, endocrinedisrupting, immunotoxic, mutagenic and not neurotoxic and they should not have any unacceptable effect on the environment [114]. These restrictions are important and should not be neglected, however, the bureaucracy involved must be revised to facilitate the process of adopting new bio-insecticides. Although there are already some bio-insecticides registered and authorized, being commercialized and used [115] they still represent a very small niche of the market [116] Faster and easier implementation of bio-insecticides research results is imperative, but regulatory requirements are so time consuming and costly that only large agrochemical companies have the resources to do so, thus, perpetuating the synthetic insecticides widespread agricultural use [21,117].

Quoting Isman in his most recent work [47]: "Perhaps it is time to refocus the attention of the research community toward the development and application of known botanicals rather than to screen more plants and isolate further novel bioactive substances that 
satisfy our curiosity but are unlikely to be of much utility". This review, as stated in the introduction, contemplates only studies performed without complex and/or expensive apparatus, with easily accessible solvents, such as ethanol and/or water, which may later be reproduced by farmers themselves. This enables a bridge to be established between raw scientific data and a more practical reality.

Taking all the information stated above, the truth is that plants are an enormous source of secondary metabolites that can have tremendous impact in wide sectors of human society; it remains to be known where to look for answers, but hopefully this review can help with that.

Author Contributions: M.d.C.B. and A.M.L.S. conceptualized and revised the paper; W.R.T. conducted the research and wrote the first draft. All authors have read and agreed to the published version of the manuscript.

Funding: This research was funded by project MACBIOPEST (MAC2/1.1a/289), program Interreg MAC 2014-2020 co-financed by DRCT (Azores Regional Government), supporting W.R. Tavares's grant, as well as by FCT—Fundação para a Ciência e Tecnologia, the European Union, QREN, FEDER, and COMPETE, through funding the cE3c center (UIDB/00329/2020) and the LAQV-REQUIMTE (UIDB/50006/2020).

Acknowledgments: Thanks are due to the University of Azores.

Conflicts of Interest: The authors declare no conflict of interest.

\section{References}

1. Thrall, P.H.; Bever, J.D.; Burdon, J.J. Evolutionary change in agriculture: The past, present and future. Evol. Appl. 2010, 3, 405-408. [CrossRef] [PubMed]

2. Tilman, D.; Balzer, C.; Hill, J.; Befort, B.L. Global food demand and the sustainable intensification of agriculture. Proc. Natl. Acad. Sci. USA 2011, 108, 20260-20264. [CrossRef] [PubMed]

3. Kopittke, P.M.; Menzies, N.W.; Wang, P.; McKenna, B.A.; Lombi, E. Soil and the intensification of agriculture for global food security. Environ. Int. 2019, 132, 105078. [CrossRef] [PubMed]

4. Donatelli, M.; Magarey, R.D.; Bregaglio, S.; Willocquet, L.; Whish, J.P.M.; Savary, S. Modelling the impacts of pests and diseases on agricultural systems. Agric. Syst. 2017, 155, 213-224. [CrossRef] [PubMed]

5. Weinberger, K.; Srinivasan, R. Farmers' management of cabbage and cauliflower pests in India and their approaches to crop protection. J. Asia Pac. Entomol. 2009, 12, 253-259. [CrossRef]

6. Satpathy, S.; Gotyal, B.S.; Babu, V.R. Role of novel insecticides in crop protection and their selectivity to natural enemies: A review. J. Environ. Biol. 2020, 41, 149-160. [CrossRef]

7. Aktar, M.W.; Sengupta, D.; Chowdhury, A. Impact of pesticides use in agriculture: Their benefits and hazards. Interdiscip. Toxicol. 2009, 2, 1-12. [CrossRef] [PubMed]

8. Bolzonella, C.; Lucchetta, M.; Teo, G.; Boatto, V.; Zanella, A. Is there a way to rate insecticides that is less detrimental to human and environmental health? Glob. Ecol. Conserv. 2019, 20, e00699. [CrossRef]

9. Mineau, P.; Downes, C.M.; Kirk, D.A.; Bayne, E.; Csizy, M. Patterns of bird species abundance in relation to granular insecticide use in the Canadian prairies. Écoscience 2005, 12, 267-278. [CrossRef]

10. Hua, J.; Relyea, R.A. East Coast vs West Coast: Effects of an insecticide in communities containing different amphibian assemblages. Freshw. Sci. 2012, 31, 787-799. [CrossRef]

11. Braak, N.; Neve, R.; Jones, A.K.; Gibbs, M.; Breuker, C.J. The effects of insecticides on butterflies-A review. Environ. Pollut. 2018, 242, 507-518. [CrossRef]

12. Koureas, M.; Tsakalof, A.; Tsatsakis, A.; Hadjichristodoulou, C. Systematic review of biomonitoring studies to determine the association between exposure to organophosphorus and pyrethroid insecticides and human health outcomes. Toxicol. Lett. 2012, 210, 155-168. [CrossRef]

13. Nicolopoulou-Stamati, P.; Maipas, S.; Kotampasi, C.; Stamatis, P.; Hens, L. Chemical pesticides and human health: The urgent need for a new concept in agriculture. Front. Public Health. 2016, 4, 148. [CrossRef]

14. Zhang, L.; Yan, C.; Guo, Q.; Zhang, J.; Ruiz-Menjivar, J. The impact of agricultural chemical inputs on environment: Global evidence from informetrics analysis and visualization. Int. J. Low Carbon Tec. 2018, 13, 338-352. [CrossRef]

15. Zhang, Q.; Li, Z.; Chang, C.H.; Lou, J.L.; Zhao, M.R.; Lu, C. Potential human exposures to neonicotinoid insecticides: A review. Environ. Pollut. 2018, 236, 71-81. [CrossRef]

16. Hawkins, N.J.; Bass, C.; Dixon, A.; Neve, P. The evolutionary origins of pesticide resistance. Biol. Rev. Camb. Philos. Soc. 2019, 94, 135-155. [CrossRef]

17. Smith, J.B. The influence of the environment on the life history of insects. In Garden and Forest, A Journal of Horticulture, Landscape Art and Forestry, 1st ed.; Sargent, C.S., Ed.; The Garden and Forest Publishing Co.: New York, NY, USA, 1897; Volume X, p. 334. 
18. Furlan, L.; Kreutzweiser, D. Alternatives to neonicotinoid insecticides for pest control: Case studies in agriculture and forestry. Environ. Sci. Pollut. Res. 2015, 22, 135-147. [CrossRef]

19. Furlan, L.; Pozzebon, A.; Duso, C.; Simon-Delso, N.; Sánchez-Bayo, F.; Marchand, P.A.; Codato, F.; Lexmond, M.B.; Bonmatin, J.-M. An update of the Worldwide Integrated Assessment (WIA) on systemic insecticides. Part 3: Alternatives to systemic insecticides. Environ. Sci. Pollut. Res. 2021, 28, 11798-11820. [CrossRef]

20. Amoabeng, B.W.; Johnson, A.C.; Gurr, G.M. Natural enemy enhancement and botanical insecticide source: A review of dual use companion plants. Appl. Entomol. Zool. 2019, 54, 1-19. [CrossRef]

21. Pavela, R. History, presence and perspective of using plant extracts as commercial botanical insecticides and farm products for protection against insects-A review. Plant Protect. Sci. 2016, 52, 229-241. [CrossRef]

22. Kumar, A.; Memo, M.; Mastinu, A. Plant behaviour: An evolutionary response to the environment? Plant Biol. 2020, 22, 961-970. [CrossRef]

23. Howe, G.A.; Jander, G. Plant immunity to insect herbivores. Annu. Rev. Plant Biol. 2008, 59, 41-66. [CrossRef]

24. Kumar, A.; Premoli, M.; Aria, F.; Bonini, S.A.; Maccarinelli, G.; Gianoncelli, A.; Memo, M.; Mastinu, A. Cannabimimetic plants: Are they new cannabinoidergic modulators? Planta 2019, 249, 1681-1694. [CrossRef]

25. War, A.R.; Paulraj, M.G.; Ahmad, T.; Buhroo, A.A.; Hussain, B.; Ignacimuthu, S.; Sharma, H.C. Mechanisms of plant defense against insect herbivores. Plant Signal. Behav. 2012, 7, 1306-1320. [CrossRef]

26. Smith, A.E.; Secoy, D.M. Forerunners of pesticides in classical Greece and Rome. J. Agric. Food Chem. 1975, 23, 1050-1055. [CrossRef]

27. Nene, Y.L. Potential of some methods described in Vrikshayurvedas in crop yield increase and disease management. Asian Agrihist. 2012, 16, 45-54.

28. Belmain, S.; Stevenson, P. Ethnobotanicals in Ghana: Reviving and modernising age-old farmer practice. Pestic. Outlook 2001, 12, 233-238. [CrossRef]

29. Grzywacz, D.; Stevenson, P.C.; Mushobozi, W.L.; Belmain, S.; Wilson, K. The use of indigenous ecological resources for pest control in Africa. Food Sec. 2014, 6, 71-86. [CrossRef]

30. Stevenson, P.C.; Belmain, S.R. Pesticidal plants in African agriculture: Local uses and global perspectives. Outlooks Pest. Manag. 2016, 27, 226-230. [CrossRef]

31. Mobolade, A.J.; Bunindro, N.; Sahoo, D.; Rajashekar, Y. Traditional methods of food grains preservation and storage in Nigeria and India. Ann. Agric. Sci. 2019, 64, 196-205. [CrossRef]

32. Deng, A.L.; Ogendo, J.O.; Owuor, G.; Bett, P.K.; Omolo, E.O.; Mugisha-Kamatenesi, M.; Mihale, J.M. Factors determining the use of botanical insect pest control methods by small-holder farmers in the Lake Victoria basin, Kenya. Afr. J. Environ. Sci. Technol. 2009, 3, 108-115. [CrossRef]

33. Kamanula, J.; Sileshi, G.W.; Belmain, S.R.; Sola, P.; Mvumi, B.M.; Nyirenda, G.K.C.; Nyirenda, S.P.; Stevenson, P.C. Farmers' insect pest management practices and pesticidal plant use in the protection of stored maize and beans in Southern Africa. Int. J. Pest. Manag. 2010, 57, 41-49. [CrossRef]

34. Nyirenda, S.P.; Sileshi, G.W.; Belmain, S.R.; Kamanula, J.F.; Mvumi, B.M.; Sola, P.; Nyirenda, G.K.C.; Stevenson, P.C. Farmers' ethno-ecological knowledge of vegetable pests and pesticidal plant use in Malawi and Zambia. Afr. J. Agric. Res. 2011, 6, 1525-1537. [CrossRef]

35. Thokozani, B.L.K.; Zulu, D.; Sileshi, G.W.; Teklehaimanot, Z.; Gondwe, D.S.B.; Sarasan, V.; Stevenson, P. Seed germination and in vitro regeneration of the African medicinal and pesticidal plant, Bobgunnia madagascariensis. Afr. J. Biotechnol. 2011, 10, 5959-5966. [CrossRef]

36. Widanapathirana, C.U.; Dassanayake, A.L.A. The use of plant parts in pest control activities in traditional Sri Lankan agricultural systems. Int. J. Sci. Technol. Res. 2013, 2, 150-152.

37. Kiruba, S.; Das, S.S.M.; Papadopoulou, S. Prospects of traditional seed storage strategies against insect infestation adopted by two ethnic communities of Tamil Nadu, southern peninsular India. Bull. Insectology 2006, 59, 129-134.

38. Karthikeyan, C.; Veeraragavathatham, D.; Karpagam, D.; Firdouse, S.A. Traditional storage practices. Indian J. Tradit. Knowl. 2009, $8,564-568$.

39. Zapico, F.L.; Aguilar, C.H.; Abistano, A.; Turner, J.C.; Reyes, L.J. Biocultural diversity of Sarangani province, Philippines: An ethno-ecological analysis. Rice Sci. 2015, 22, 138-146. [CrossRef]

40. Sinzogan, A.A.C.; Kossou, D.K.; Atachi, P.; Huis, A. Participatory evaluation of synthetic and botanical pesticide mixtures for cotton bollworm control. Int. J. Trop. Insect Sci. 2006, 26, 246-255. [CrossRef]

41. Coulibaly, O.; Mbila, D.; Sonwa, D.J.; Adesina, A.; Bakala, J. Responding to economic crisis in Sub-Saharan Africa: New farmerdeveloped pest management strategies in cocoa-based plantations in Southern Cameroon. Integr. Pest. Manag. Rev. 2002, 7, 165-172. [CrossRef]

42. Mugisha-Kamatenesi, M.; Deng, A.L.; Ogendo, J.O.; Omolo, E.O.; Mihale, M.J.; Otim, M.; Buyungo, J.P.; Bett, P.K. Indigenous knowledge of field insect pests and their management around lake Victoria basin in Uganda. Afr. J. Environ. Sci. Technol. 2008, 2, 342-348. [CrossRef]

43. Boulogne, I.; Petit, P.; Ozier-Lafontaine, H.; Desfontaines, L.; Loranger-Merciris, G. Insecticidal and antifungal chemicals produced by plants: A review. Environ. Chem. Lett. 2012, 10, 325-347. [CrossRef] 
44. Dougoud, J.; Toepfer, S.; Bateman, M.; Jenner, W.H. Efficacy of homemade botanical insecticides based on traditional knowledge. A review. Agron. Sustain. Dev. 2019, 39, 1-22. [CrossRef]

45. Gonzalez-Coloma, A.; Reina, M.; Diaz, C.E.; Fraga, B.M.; Santana-Meridas, O. Natural product-based biopesticides for insect control. In Elsevier Reference Module in Chemistry, Molecular Sciences and Chemical Engineering; Elsevier: Waltham, MA, USA, 2013; pp. 1-57. [CrossRef]

46. Isman, M.B.; Grieneisen, M.L. Botanical insecticide research: Many publications, limited useful data. Trends Plant Sci. 2014, 19, 140-145. [CrossRef]

47. Isman, M.B. Botanical insecticides in the twenty-first century-fulfilling their promise? Annu. Rev. Entomol. 2020, 65, 233-249. [CrossRef]

48. Constantine, K.L.; Kansiime, M.K.; Mugambi, I.; Nunda, W.; Chacha, D.; Rware, H.; Makale, F.; Mulema, J.; Lamontagne-Godwin, J.; Williams, F.; et al. Why don't smallholder farmers in Kenya use more biopesticides? Pest. Manag. Sci. 2020, 76, 3615-3625. [CrossRef] [PubMed]

49. The Plant List Database. Available online: http://www.theplantlist.org (accessed on 31 January 2021).

50. Isman, M.B. Bridging the gap: Moving botanical insecticides from the laboratory to the farm. Ind. Crops Prod. 2017, 110, 10-14. [CrossRef]

51. Köhler, H.-R.; Triebskorn, R. Wildlife ecotoxicology of pesticides: Can we track effects to the population level and beyond? Science 2013, 341, 759-765. [CrossRef]

52. Ndakidemi, B.; Mtei, K.; Ndakidemi, P.A. Impacts of synthetic and botanical pesticides on beneficial insects. Agric. Sci. 2016, 7, 364-372. [CrossRef]

53. Turchen, L.M.; Cosme-Júnior, L.; Guedes, R.N.C. Plant-derived insecticides under meta-analyses: Status, biases, and knowledge gaps. Insects 2020, 11, 532. [CrossRef]

54. Mkenda, P.; Mwanauta, R.; Stevenson, P.C.; Ndakidemi, P.; Mtei, K.; Belmain, S.R. Extracts from field margin weeds provide economically viable and environmentally benign pest control compared to synthetic pesticides. PLoS ONE. 2015, 10, e0143530. [CrossRef] [PubMed]

55. Lovatto, P.B.; Goetze, M.; Thomé, G.C.H. Extracts effect of wild plants of the Solanaceae family on Brevicoryne brassicae control in cabbage (Brassica oleracea var. acephala) Cienc. Rural 2004, 34, 971-978. [CrossRef]

56. Rando, J.S.S.; Lima, C.B.; Batista, N.A.; Feldhaus, D.C.; Lourenço, C.C.; Polonio, V.D.; Ávila, R.R.; Malanotte, M.L. Plant extracts in the control of aphids Brevicoryne brassicae (L.) and Myzus persicae (Sulzer). Semin. Cienc. Agrar. 2011, 32, 503-512. [CrossRef]

57. Amoabeng, B.W.; Stevenson, P.C.; Pandeya, S.; Mochiahb, M.B.; Gurre, M.G. Insecticidal activity of a native Australian tobacco, Nicotiana megalosiphon Van Heurck \& Muell. Arg. (Solanales: Solanaceae) against key insect pests of brassicas. Crop. Prot. 2018, 106, 6-12. [CrossRef]

58. Santos, T.M.; Costa, N.P.; Torres, A.L.; Júnior, A.L.B. Effect of neem extract on the cotton aphid. Pesqui. Agropecu. Bras. 2004, 39, 1071-1076. [CrossRef]

59. Hernández-Castro, E.; Utrera-Landa, V.; Villanueva-Jiménez, J.A.; Rodríguez-Lagunes, D.A.; Ojeda-Ramírez, M.M. Neem extracts on Aphis nerii behaviour and papaya ringspot virus transmission. J. Agric. Univ. Puerto Rico 2005, 89, 75-84. [CrossRef]

60. Esparza-Díaz, G.; López-Collado, J.; Villanueva-Jiménez, J.A.; Osorio-Acosta, F.; Otero-Colina, G.; Camacho-Díaz, E. Azadirachtin concentration, insecticide efficacy and phytotoxicity of four neem Azadirachta indica A. Juss. extracts. Agrociencia 2010, 44, 821-833.

61. Hossain, M.A.; Haque, M.A. Efficacy of some indigenous plant extracts as grain protectant against pulse beetle, Callosobruchus chinensis L. J. Agrofor. Environ. 2010, 4, 197-202.

62. Phambala, K.; Tembo, Y.; Kasambala, T.; Kabambe, V.H.; Stevenson, P.C.; Belmain, S.R. Bioactivity of common pesticidal plants on fall armyworm larvae (Spodoptera frugiperda). Plants 2020, 9, 112. [CrossRef]

63. Silva, G.; Rodríguez, J.C.; Blanco, C.A.; Lagunes, A. Bioactivity of a water extract of boldus (Peumus boldus Molina) against Spodoptera frugiperda (J.E. Smith) and Helicoverpa zea Boddie (Lepidoptera: Noctuidae). Chil. J. Agric. Res. 2013, 73, 135-141. [CrossRef]

64. Mobki, M.; Safavi, S.A.; Safaralizadeh, M.H.; Panahi, O. Toxicity and repellency of garlic (Allium sativum L.) extract grown in Iran against Tribolium castaneum (Herbst) larvae and adults. Arch. Phytopathol. Pflanzenschutz 2014, 47, 59-68. [CrossRef]

65. Pavela, R. Extract from the roots of Saponaria officinalis as a potential acaricide against Tetranychus urticae. J. Pest. Sci. 2017, 90, 683-692. [CrossRef]

66. Amoabeng, B.W.; Gurr, G.M.; Gitau, C.W.; Nicol, H.I.; Munyakazi, L.; Stevenson, P.C. Tri-trophic insecticidal effects of African plants against cabbage pests. PLoS ONE. 2013, 8, e78651. [CrossRef]

67. Kibrom, G.; Kebede, K.; Weldehaweria, G.; Dejen, G.; Mekonen, S.; Gebreegziabher, E.; Nagappan, R. Field evaluation of aqueous extract of Melia azedarach Linn. seeds against cabbage aphid, Brevicoryne brassicae Linn. (Homoptera: Aphididae), and its predator Coccinella septempunctata Linn. (Coleoptera: Coccinellidae). Arch. Phytopathol. Pflanzenschutz 2012, 45, 1273-1279. [CrossRef]

68. Kestenholz, C.; Stevenson, P.C.; Belmain, S.R. Comparative study of field and laboratory evaluations of the ethnobotanical Cassia sophera L. (Leguminosae) for bioactivity against the storage pests Callosobruchus maculatus (F.) (Coleoptera: Bruchidae) and Sitophilus oryzae (L.) (Coleoptera: Curculionidae). J. Stored Prod. Res. 2007, 43, 79-86. [CrossRef]

69. Azad, A.K.; Sardar, A.; Yesmin, N.; Rahman, M.; Islam, S. Eco-friendly pest control in cucumber (Cucumis sativa L.) field with botanical pesticides. Nat. Resour. 2013, 4, 404-409. [CrossRef] 
70. Kumar, R.; Ahad, I.; Sheikh, A.A.; Showkat, A.; Arifie, U.; Dorjey, S. Bioactive plant extracts an alternate to chemicals for management of armyworm infesting oats. Int. J. Curr. Microbiol. App. Sci. 2017, 6, 129-134. [CrossRef]

71. Baidoo, P.K.; Mochiah, M.B. Comparing the effectiveness of garlic (Allium sativum L.) and hot pepper (Capsicum frutescens L.) in the management of the major pests of cabbage Brassica oleracea (L.). Sustain. Agric. Res. 2016, 5, 83-91. [CrossRef]

72. Mboussi, S.B.; Ambang, Z.; Kakam, S.; Beilhe, L.B. Control of cocoa mirids using aqueous extracts of Thevetia peruviana and Azadirachta indica. Cogent Food Agric. 2018, 4, 1430470. [CrossRef]

73. Fite, T.; Tefera, T.; Negeri, M.; Damte, T. Effect of Azadirachta indica and Milletia ferruginea extracts against Helicoverpa armigera (Hubner) (Lepidoptera: Noctuidae) infestation management in chickpea. Cogent Food Agric. 2020, 6, 1712145. [CrossRef]

74. Murovhi, J.; Phophi, M.M.; Mafongoya, P. Efficacy of plant materials in controlling aphids on Okra (Abelmoschus esculentus L. Moench) in Limpopo Province of South Africa. Agronomy 2020, 10, 1968. [CrossRef]

75. Ertürk, Ö.; Şekrtoğlu, V.; Koç, A.; Kalkan, Y. Antifeedant and toxicity effects of some plant extracts on Yponomeuta malinellus Zell. (Lep.: Yponomeutidae). J. Plant Prot. Res. 2004, 44, 165-174.

76. Tavares, W.S.; Grazziotti, G.H.; Júnior, A.A.S.; Freitas, S.S.; Consolaro, H.N.; Ribeiro, P.E.A.; Zanuncio, J.C. Screening of extracts of leaves and stems of Psychotria spp. (Rubiaceae) against Sitophilus zeamais (Coleoptera: Curculionidae) and Spodoptera frugiperda (Lepidoptera: Noctuidae) for maize protection. J. Food Prot. 2013, 76, 1892-1901. [CrossRef]

77. Almeida, V.T.; Ramos, V.M.; Saqueti, M.B.; Gorni, P.H.; Pacheco, A.C.; Leão, R.M. Bioactivity of ethanolic extracts of Euphorbia pulcherrima on Spodoptera frugiperda (J.E. Smith) (Lepidoptera: Noctuidae). Afr. J. Biotechnol. 2017, 16, 615-622. [CrossRef]

78. Salinas-Sánchez, D.O.; Aldana-Llanos, L.; Valdés-Estrada, M.E.; Gutiérrez-Ochoa, M.; Valladares-Cisneros, G.; Rodríguez-Flores, E. Insecticidal activity of Tagetes erecta extracts on Spodoptera frugiperda (Lepidoptera: Noctuidae). Fla. Entomol. 2012, 95, 428-432. [CrossRef]

79. Nikkon, F.; Habib, M.R.; Karim, M.R.; Ferdousi, Z.; Rahman, M.M.; Haque, M.E. Insecticidal activity of flower of Tagetes erecta L. against Tribolium castaneum (Herbst). Res. J. Agric. Biol. Sci. 2009, 5, 748-753.

80. Chermenskaya, T.D.; Stepanycheva, E.A.; Shchenikova, A.V.; Chakaeva, A.S. Insectoacaricidal and deterrent activities of extracts of Kyrgyzstan plants against three agricultural pests. Ind. Crops Prod. 2010, 32, 157-163. [CrossRef]

81. Afify, A.E.-M.M.R.; El-Beltagi, H.S.; Fayed, S.A.; Shalaby, E.A. Acaricidal activity of different extracts from Syzygium cumini L. Skeels (Pomposia) against Tetranychus urticae Koch. Asian Pac. J. Trop. Biomed. 2011, 1, 359-364. [CrossRef]

82. Numa, S.; Rodríguez, L.; Rodríguez, D.; Coy-Barrera, E. Susceptibility of Tetranychus urticae Koch to an ethanol extract of Cnidoscolus aconitifolius leaves under laboratory conditions. Springerplus 2015, 4, 338. [CrossRef]

83. Zhang, Y.-N.; He, P.; Xue, J.-P.; Guo, Q.; Zhu, X.-Y.; Fang, L.-P.; Li, J.-B. Insecticidal activities and biochemical properties of Pinellia ternata extracts against the beet armyworm Spodoptera exigua. J. Asia Pac. Entomol. 2017, 20, 469-476. [CrossRef]

84. Silva, C.G.V.; Oliveira, J.C.S.; Camara, C.A.G. Insecticidal activity of the ethanolic extract from Croton species against Plutella xylostella L. (Lepidoptera: Plutellidae). Rev. Fac. Nac. Agron. Medellín 2018, 71, 8543-8551. [CrossRef]

85. Ahmed, M.; Peiwen, Q.; Gu, Z.; Liu, Y.; Sikandar, A.; Hussain, D.; Javeed, A.; Shafi, J.; Iqbal, M.F.; An, R.; et al. Insecticidal activity and biochemical composition of Citrullus colocynthis, Cannabis indica and Artemisia argyi extracts against cabbage aphid (Brevicoryne brassicae L.). Sci. Rep. 2020, 10, 522. [CrossRef] [PubMed]

86. El-Ghar, G.E.S.A.; Khalil, M.E.; Eid, T.M. Some biochemical effects of plant extracts in the black cutworm, Agrotis ipsilon (Hufnagel) (Lep., Noctuidae). J. Appl. Ent. 1996, 120, 477-482. [CrossRef]

87. Malarvannan, S.; Subashini, H.D. Efficacy of Dodonaea angustifolia crude extracts against spotted bollworm, Earias vitella (Fab.) (Lepidoptera: Noctuidae). J. Entomol. 2007, 4, 243-247. [CrossRef]

88. Adeniyi, S.A.; Orjiekwe, C.L.; Ehiagbonare, J.E.; Arimah, B.D. Preliminary phytochemical analysis and insecticidal activity of ethanolic extracts of four tropical plants (Vernonia amygdalina, Sida acuta, Ocimum gratissimum and Telfaria occidentalis) against beans weevil (Acanthscelides obtectus). Int. J. Phys. Sci. 2010, 5, 753-762. [CrossRef]

89. Santos, W.L.; Freire, M.G.M.; Bogorni, P.C.; Vendramim, J.D.; Macedo, M.L.R. Effect of the aqueous extracts of the seeds of Talisia esculenta and Sapindus saponaria on fall armyworm. Braz. Arch. Biol. Technol. 2008, 51, 373-383. [CrossRef]

90. Santos, P.C.; Santos, V.H.M.; Mecina, G.F.; Andrade, A.R.; Fegueiredo, P.A.; Moraes, V.M.O.; Silva, L.P.; Silva, R.M.G. Insecticidal activity of Tagetes sp. on Sitophilus zeamais Mots. Int. J. Environ. Agric. Res. 2016, 2, 31-38.

91. Rioba, N.B.; Stevenson, P.C. Opportunities and scope for botanical extracts and products for the management of fall armyworm (Spodoptera frugiperda) for smallholders in Africa. Plants 2020, 9, 207. [CrossRef]

92. Ikbal, C.; Pavela, R. Essential oils as active ingredients of botanical insecticides against aphids. J. Pest. Sci. 2019, 92, 971-986. [CrossRef]

93. Ebadollahi, A.; Ziaee, M.; Palla, F. Essential oils extracted from different species of the Lamiaceae plant family as prospective bioagents against several detrimental pests. Molecules 2020, 25, 1556. [CrossRef]

94. Mwanauta, R.W.; Mtei, K.A.; Ndakidemi, P.A. Prospective bioactive compounds from Vernonia amygdalina, Lippia javanica, Dysphania ambrosioides and Tithonia diversifolia in controlling legume insect pests. Agric. Sci. 2014, 5, 1129-1139. [CrossRef]

95. Govindan, K.; Nelson, S.J. Insecticidal activity of twenty plant powders on mortality, adult emergence of Sitophilus oryzae L. and grain weight loss in paddy. J. Biopestic. 2009, 2, 169-172.

96. Asadollahi, A.; Khoobdel, M.; Zahraei-Ramazani, A.; Azarmi, S.; Mosawi, S.H. Effectiveness of plant-based repellents against different Anopheles species: A systematic review. Malar. J. 2019, 18, 436. [CrossRef] 
97. Senthil-Nathan, S. A Review of resistance mechanisms of synthetic insecticides and botanicals, phytochemicals, and essential oils as alternative larvicidal agents against mosquitoes. Front. Physiol. 2020, 10, 1591. [CrossRef]

98. Aihetasham, A.; Rasib, K.Z.; Hasan, S.R.; Bodlah, I. Effect of Carica papaya, Helianthus annus and Bougainvillea glabra aqueous extracts against termite, Heterotermes indicola (Isoptera: Rhinotermitidae). Punjab Univ. J. Zool. 2017, 32, 51-56.

99. Utami, R.A.; Awan, A.; Rumahlatu, D.; Tuapattinaya, P.M.J. The effects of ethanol extract and pepaya leaf water extract (Carica papaya Linn.) as biopesticides againts soil termites (Coptotermes curvinaghtus Holmgren.). Int. J. Health Med. Curr. Res. 2017, 2 503-508. [CrossRef]

100. Jacques, D.T.; Safiou, A.; Jédirfort, H.; Souaibou, F. In Vitro effect of the ethanolic extract of Tephrosia Vogelii on Rhipicephalus Sanguineus in Abomey-Calavi. Avicenna J. Phytomed. 2015, 5, 247-259. [PubMed]

101. Adenubi, O.T.; Fasina, F.O.; McGaw, L.J.; Eloff, J.N.; Naidoo, V. Plant extracts to control ticks of veterinary and medical importance: A review. S. Afr. J. Bot. 2016, 105, 178-193. [CrossRef]

102. Sarkar, S.C.; Wang, E.; Wu, S.; Lei, Z. Application of trap cropping as companion plants for the management of agricultural pests: A review. Insects 2018, 9, 128. [CrossRef]

103. Valladares, G.; Defago, M.T.; Palacios, S.; Carpinella, M.C. Laboratory evaluation of Melia azedarach (Meliaceae) extracts against the elm leaf beetle (Coleoptera: Chrysomelidae). J. Econ. Entomol. 1997, 90, 747-750. [CrossRef]

104. Medhini, N.; Divakar, Y.G.; Manjulakumari, D. Effect of Calendula officinalis extracts on the nutrient components of different tissues of tobacco cutworm, Spodoptera litura Fabricius. J. Biopestic. 2012, 5, 139-144.

105. Iqbal, J.; Jilani, G.; Aslam, M. Growth inhibiting effects of three different plant extracts on Tribolium castaneum (Herbst) (Tenebrionidae: Coleoptera). J. Bioresour. Manage. 2015, 2, 40-48. [CrossRef]

106. Harder, M.J.; Tello, V.E.; Giliomee, J.H. The acaricidal effect of ethanolic extracts of Chenopodium quinoa Willd. on Tetranychus urticae Koch (Acari: Tetranychidae). Afr. Entomol. 2016, 24, 50-60. [CrossRef]

107. Vukajlović, F.N.; Pešić, S.B.; Tanasković, S.T.; Predojević, D.Z.; Gvozdenac, S.M.; Prvulović, D.M.; Bursić, V.P. Efficacy of Echium spp. water extracts as post-harvest grain protectants against Plodia interpunctella. Rom. Biotechnol. Lett. 2019, 24, 761-769. [CrossRef]

108. Mossa, A.-T.H.; Mohafrash, S.M.M.; Chandrasekaran, N. Safety of natural insecticides: Toxic effects on experimental animals. BioMed Res. Int. 2018, 2018, 4308054. [CrossRef]

109. Joshi, D.R.; Adhikari, N. An overview on common organic solvents and their toxicity. J. Pharm. Res. Int. 2019, 28, 1-18. [CrossRef]

110. Chowdhury, A.; Odame, H.H.; Thompson, S.; Hauser, M. Enhancing farmers' capacity for botanical pesticide innovation through video-mediated learning in Bangladesh. Int. J. Agric. Sustain. 2015, 13, 326-349. [CrossRef]

111. Vekemans, M.-C.; Marchand, P.A. The fate of biocontrol agents under the European phytopharmaceutical regulation: How this regulation hinders the approval of botanicals as new active substances. Environ. Sci. Pollut. Res. 2020, $27,39879-39887$. [CrossRef] [PubMed]

112. European Commission (EC): Sustainable Use of Pesticides. Available online: https://ec.europa.eu/food/plant/pesticides/ sustainable_use_pesticides_en (accessed on 20 April 2021).

113. United States Environmental Protection Agency (EPA): Biopesticides. Available online: https://www.epa.gov/pesticides/ biopesticides (accessed on 20 April 2021).

114. EUR-Lex-Access to European Union Law: Regulation (EC) No 1107/2009 of the European Parliament and of the Council of 21 October 2009 Concerning the Placing of Plant Protection Products on the Market and Repealing Council Directives 79/117/EEC and 91/414/EEC. Available online: https:/ / eur-lex.europa.eu/legal-content/EN/TXT/?uri=CELEX:32009R1107 (accessed on 20 April 2021).

115. European Commission (EC): EU Pesticides Database. Available online: https://ec.europa.eu/food/plant/pesticides/eupesticides-database/active-substances/? event=search.as (accessed on 20 April 2021).

116. Samada, L.H.; Tambunan, U.S.F. Biopesticides as promising alternatives to chemical pesticides: A review of their current and future status. Online J. Biol. Sci. 2020, 20, 66-76. [CrossRef]

117. Isman, M.B. Botanical insecticides: For richer, for poorer. Pest. Manag. Sci. 2008, 64, 8-11. [CrossRef] 